\title{
Influence of the irrigation technique and strategies on the nitrogen cycle
} and budget: a review

Mohammad Barakat $^{\mathrm{a}, \mathrm{b}}$, Bruno Cheviron ${ }^{\mathrm{a}, \dagger}$, Rafael Angulo-Jaramillo ${ }^{\mathrm{b}}$

a IRSTEA, UMR G-EAU "Gestion de l'Eau, Acteurs et Usages", 361 rue Jean-François Breton, BP 5095, 34196 Montpellier Cedex 5, France

${ }^{\mathrm{b}}$ Université de Lyon, UMR 5023 Laboratoire d'Ecologie des Hydrosystèmes Naturels et Anthropisés, CNRS, ENTPE, Université Lyon 1, 3 rue Maurice Audin, 69518 Vaulx-enVelin, France.

$\dagger$ Corresponding author: bruno.cheviron@irstea.fr 


\section{Abstract}

The objective of this review is to remedy the lack of knowledge about the expected relationship between the irrigation techniques (flood irrigation, sprinkler irrigation, surface and subsurface drip irrigation) and the nitrogen transformations (fixation, mineralization, immobilization and nitrification) or fluxes (denitrification, runoff, volatilization and lixiviation) in agricultural contexts. This study investigates thus the various controls on the nitrogen cycle and budget, either site-specific (soil $\mathrm{C} / \mathrm{N}$ ratio, $\mathrm{pH}$, salinity, texture and temperature) or corresponding to deliberate strategies in water and nitrogen management. The comprehensive view gained from the gathered literature elements identifies the local variations (in space and time) of soil water content profile as both the strongest control and the control most directly related to the irrigation technique and to the practitioner's decisions. In the overall picture, flood irrigation and sprinkler irrigation are the techniques in which most transformations or fluxes may be enhanced or reduced, also with the risks associated with non-optimal practices. By contrast, subsurface drip irrigation seems the technique with the least unwanted impacts. Besides the academic aspects (bringing together scattered literature elements) an outcome of this review is thus to facilitate decision-making regarding the choice and/or use of irrigation-fertilization techniques and strategies (doses and scheduling) for given agro-pedoclimatic contexts, also for combined agricultural production, economic and site preservation objectives. 
Author-produced version of the article published in Agricultural Water Management, 2016, №178, p. 225-238.

The original publication is available at http://www.sciencedirect.com/science/article/pii/S0378377416303833

Doi: 10.1016/j.agwat.2016.09.027

\section{Introduction}

Increased anthropic pressure and growing food demands exerted on cultivated areas have lead to the intensification of agriculture (Galloway et al., 2008; Keys and McConnell, 2005; Konstantinou et al., 2006; Lambin et al., 1991; Vitousek et al., 1997) at the fear of pending runaway Earth contaminations, with the necessity to identify and promote sustainable practices (Alexandratos and Bruinsma, 2012; Tilman et al., 2011). Excessive nutrient and pesticides applications represent one of the most common causes of degradation in surface water and groundwater quality, which makes risk assessment a crucial part of any agricultural management at the plot, catchment and basin scale (Flury, 1993; Long and Sun, 2012; Reichenberger et al., 2007; Rivett et al. 2008). In particular, a comprehensive view of the merits and drawbacks of irrigation and fertilisation strategies requires modelling techniques as well as knowledge of the technological and legal angles (Sutton et al., 2011; van Grinsven et al. 2012). The site-specific optimisation of practices is a wide concern for stakeholders, farmers, agronomists, soil physicists and biogeochemists, in which the first degrees of freedom are the choice of the irrigation technology and technique (FI: flood irrigation, SI: sprinkler irrigation, DI: drip irrigation, SDI: subsurface drip irrigation).

To start from well-established knowledge, soil nitrogen availability has been long known to influence crop and root growth thus to have a direct impact on crop yield, attributing increased death rates for young individuals and leaf yellowing to insufficient nitrogen uptake (Lloyd, 1993; Niste et al., 2013). Conversely, an over-supply of nitrogen into the root zone may also decrease crop yield by stimulating stem growth to the detriment of root growth, grain filling or sugar content, leaving the non-absorbed nitrogen available for lixiviation (Thorburn et al., 2003a; Zahran, 1999). Excessive nitrogen applications are also prone to inhibit the action of the nitrogenase enzyme responsible for the biological fixation of nitrogen (Muthukumarasamy et al., 1999). In complement, any purposive fertigation strategy should also limit, if not suppress, the nitrogen losses towards the atmosphere through denitrification (i.e. the multi-stage conversion of nitrates to nitrogen gas) and ammonia volatilization (Kroeze et al., 2003). The decisions on how, when and where to apply nitrogen should thus arise from a fine understanding of the nitrogen cycle, including the estimation of mineralization rates (Cabrera, 1993; Fierer and Schimel, 2002; Jackson et al., 2008) and that of plant needs at best (Mmolawa and Or, 2000; Soussi et al., 1998; Valé et al., 2007). In all genericity, both crop productivity and the nitrogen budget also depend on the timing of 
fertigation (or fertilization) within irrigation events (Ebrahimian et al., 2013), the type of molecules used (Hanson et al., 2006), soil properties (Zotarelli et al., 2007), the location of the fertilizer (Siyal et al., 2012), the splitting of nitrogen doses (Yoseftabar et al., 2012) and the frequency of nitrogen inputs (Gheysari et al., 2009).

In a schematic overview, Fig. 1 shows the quantities of interest for the current study, especially the nine forms under which nitrogen appears in the nitrogen cycle (Robertson and Groffman, 2007), sorted here by decreasing oxidation states: nitrate $\left(\mathrm{NO}_{3}^{-},+5\right)$, nitrogen dioxide $\left(\mathrm{NO}_{2},+4\right)$, nitrite $\left(\mathrm{NO}_{2}^{-},+3\right)$, nitric oxide $(\mathrm{NO},+2)$, nitrous oxide $\left(\mathrm{N}_{2} \mathrm{O},+1\right)$, dinitrogen gas $\left(\mathrm{N}_{2}, 0\right)$, ammonia $\left(\mathrm{NH}_{3},-3\right)$, ammonium $\left(\mathrm{NH}_{4}{ }^{+},-3\right)$ and organic nitrogen $(\mathrm{R}$ $\left.\mathrm{NH}_{2},-3\right)$. The dinitrogen gas represents about $90 \%$ of the total nitrogen but the molecule must be split by lightning (into ammonium) or by symbiotic fixation to become available for plants, and the activity of the nitrogen fixing bacteria depend on the local soil conditions: organic matter, water content and temperature (Zahran, 1999). The organic nitrogen also necessitates the action of soil microorganisms (mineralization into ammonium) prior to its absorption by plant roots (Jackson et al., 2008). In addition to ammonium or direct symbiotic fixation, nitrates are the last source of nitrogen for the plant, through root uptake. Finally, fertilization consists in the input of ammonium or nitrates, while lixiviation designates the loss of nitrates by drainage. 


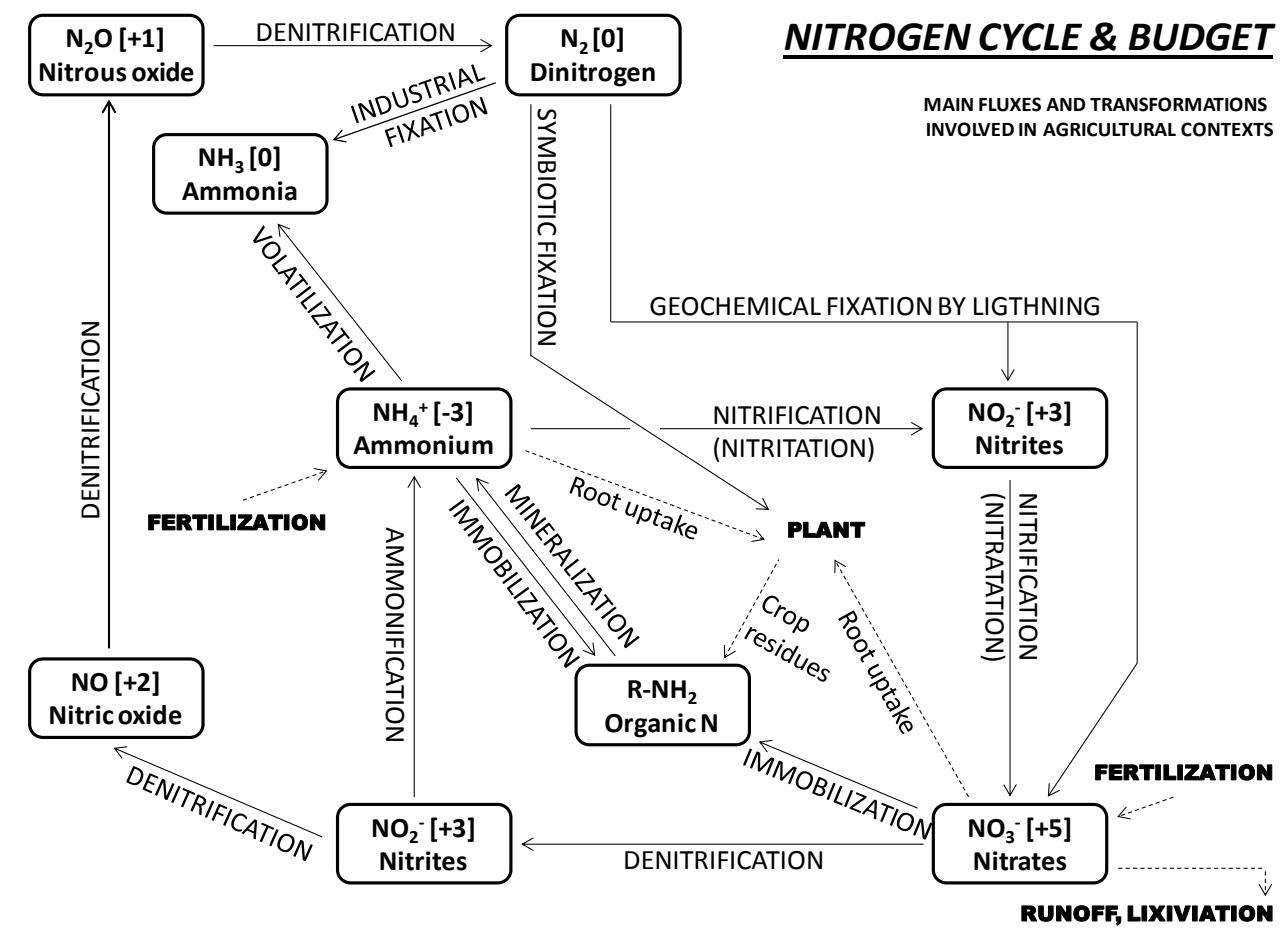

Figure 1 - Schematic overview of the nitrogen cycle and budget, showing the main nitrogen fluxes and transformations in agricultural contexts.

Quite surprisingly, there is still a need for the literature to investigate how several elements of the nitrogen cycle may be influenced by the chosen irrigation and fertilization technique but also strategy (e.g. dates of application, doses applied, formulation of the fertiliser) with an expected impact on the nitrogen budget, thus on the environmental footprint, as well as on several key performance indicators: crop yield, water and nitrogen use efficiency and operating profitability. To our knowledge, these issues have not been explicitly addressed so far, even when discussing the global agricultural or environmental perspectives associated with the nitrogen cycle, as affected by human activities (Bassirirad, 2000; Galloway et al., 2004; Gruber and Galloway, 2008; van Groeningen et al., 2015; Ward, 2012) . The purpose of the current study is to remedy this lack by collecting results, controversies, recommendations and open questions, from existing but dispersed information. This review aims at eventually outlining the influence of the irrigation techniques and associated fertilization strategies on the nitrogen transformations (cycle) and fluxes (budget) through the direct or indirect effects of irrigation techniques on the controlling factors for nitrogen availability for plant roots (soil $\mathrm{C} / \mathrm{N}$ ratio, $\mathrm{pH}$, salinity, temperature, texture, water content) and nitrogen fate (fertilizer location and scheduling of applications, soil texture, types of molecules used, water content). 
This review leans on 177 literature sources to suggest or establish the existence of a correlation between the irrigation techniques and soil nitrogen transformations or fluxes, focusing on these described in Fig.1. Prior to more detailed investigations in the manuscript, several popular clues of this correlation may be sought in that (i) nitrogen losses by lixiviation occur when irrigation reaches its peak in intensity (Kroeze et al., 2003), (ii) even a slight increase in soil water content may drastically enhance denitrification (Davidson, 1992), (iii) the use of new fertigation techniques makes nitrogen application far more efficient (Valé et al., 2007), (iv) irrigation water is the driving force for nitrogen movements, availability and transformation (Sanchez-Martin et al., 2008) and (v) nitrogen mineralization is stronger in regularly irrigated soils than in non-irrigated or irregularly irrigated soils (Valé et al., 2007). These points and other effects of the irrigation techniques and strategies are discussed in this review, first from the angle of nitrogen transformations in Section 2 (fixation, immobilization, mineralization and nitrification) then from that of nitrogen fluxes in Section 3 (denitrification, lixiviation, runoff and volatilization). Section 4 provides elements of discussion around a typical agricultural situation assembled from literature elements then Section 5 offers a brief conclusion on the expected first-order effects of the irrigation technique (and associated fertilization) on the nitrogen cycle and budget.

\section{Influence of the irrigation techniques on nitrogen transformations}

\subsection{Nitrogen fixation}

\subsubsection{Basics of nitrogen fixation}

Nitrogen fixation is the process by which the stable dinitrogen atmospheric gas $\left(\mathrm{N}_{2}\right.$ in Fig.1) is converted into "bioaccessible" forms of nitrogen available for biosynthesis. The process can be represented by the following reaction:

$2 \mathrm{~N}_{2}(\mathrm{~g})+8 \mathrm{H}^{+}+8 \mathrm{e}^{-} \rightarrow 2 \mathrm{NH}_{3}+\mathrm{H}_{2}$

Fixation occurs either in non-biological (fixation by lightning or industrial fixation) or biological (symbiotic fixation) or processes (Galloway et al. 1995, Zahran 1999).

- Geochemical fixation by lightning leads to $\mathrm{NO}_{\mathrm{x}}$ ions, from the break of the triply bonded $\mathrm{N}_{2}$ molecules and their recombination with atmospheric oxygen (Fowler et al., 2013). 
- Industrial fixation of gaseous $\mathrm{N}_{2}$ through the Haber-Bosch process for the production of ammonia under high temperature and pressure conditions writes in simplified form:

$\mathrm{N}_{2}+3 \mathrm{H}_{2} \rightarrow 2 \mathrm{NH}_{3}$

- Symbiotic fixation necessitates the action of the nitrogenase enzymes. Several species of rhizobium bacteria, living in the nodules of plant roots (ex. Leguminosae family) near the soil-atmosphere interface, perform nitrogen fixation in the course of their metabolism.

\subsubsection{Influence of the irrigation technique on nitrogen fixation}

Table 1 lists the soil variables (soil $\mathrm{pH}$, salinity, temperature and water content, by alphabetical order) that control symbiotic nitrogen fixation, with the suggested influence of the irrigation techniques, mainly through their effects on soil water content.

Table 1 - Soil variables that control symbiotic nitrogen fixation, with the expected influence of the irrigation technique (FI: flood irrigation, SI: sprinkler irrigation, DI: drip irrigation, SDI: subsurface drip irrigation). Besides additional comments, this influence is noted (+) for "favorable" and (-) for "unfavorable".

\begin{tabular}{|c|c|c|c|c|c|c|}
\hline \multicolumn{3}{|c|}{ Data } & \multicolumn{4}{|c|}{ Influence on fixation } \\
\hline Variable & Effects & References & FI & SI & DI & SDI \\
\hline $\mathrm{pH}$ & $\begin{array}{c}\text { Acidic }(\mathrm{pH}<4) \text { or alkaline }(\mathrm{pH}>8) \\
\text { soils decrease nodulation thus } \\
\text { nitrogen fixation. Significant } \\
\text { water movements tend to flush the } \\
\text { anions. }\end{array}$ & $\begin{array}{c}\text { Bordeleau and Prévost, 1994; Kumar } \\
\text { and Shivay, } 2008 .\end{array}$ & $\begin{array}{r}\text { Local } \mathrm{pl} \\
\text { decrease } \mathrm{d} \mathrm{t} \\
\text { large wat } \\
\text { flows }(-\end{array}$ & er to & & $\begin{array}{l}\mathrm{l}_{\mathrm{DI}}<\mathrm{pH}_{\mathrm{SDI}} \\
(-) \quad(+)\end{array}$ \\
\hline Salinity & $\begin{array}{l}\text { Adverse: limits bacterial activity, } \\
\text { population and efficiency on the } \\
\text { existing nodules, prevents the } \\
\text { development of new nodules. } \\
\text { Noticeable differences between } \\
\text { irrigation techniques. }\end{array}$ & $\begin{array}{c}\text { Berstein and Ogata, 1966; Bruning and } \\
\text { Rozema, 2013; Garg and Chandel, } \\
\text { 2011; Hafeez et al., 1988; Lamm et al., } \\
\text { 2007; Lindström et al., 1985; Rao et } \\
\text { al., 2002; Sanchez-Diaz et al. 1982; } \\
\text { Silva \& Uchida 2000. Soussi et al. } \\
\text { 1998,. }\end{array}$ & $\begin{array}{l}\text { More } \\
\text { salinity in } \\
\text { the root } \\
\text { zone (-) }\end{array}$ & $\begin{array}{l}\text { Le } \\
\text { salini } \\
\text { the } r \\
\text { zone }\end{array}$ & $\begin{array}{l}\text { ity in } \\
\text { root } \\
(+)\end{array}$ & $\begin{array}{l}\text { More } \\
\text { salinity on } \\
\text { the edge of } \\
\text { the root } \\
\text { zone (-) }\end{array}$ \\
\hline $\begin{array}{l}\text { Temperature } \\
\text { (T) }\end{array}$ & $\begin{array}{c}\mathrm{T}<13 \text { or } \mathrm{T}>35^{\circ} \mathrm{C} \text { inhibits } \\
\text { nitrogenase activity thus reduces } \\
\text { nodulation and fixation. Optimum } \\
\mathrm{T} \text { close to } 30^{\circ} \mathrm{C} . \mathrm{T} \text { is affected by } \\
\text { the irrigation technique. }\end{array}$ & $\begin{array}{l}\text { Bell et al., 1998; Bordeleau and } \\
\text { Prévost, 1994; Colaizzi et al., 2004; Lü } \\
\text { et al., 2015; Rice et al., 1995; Zahran, } \\
\text { 1999. . }\end{array}$ & & $\mathrm{T}_{\mathrm{S}}$ & & \\
\hline $\begin{array}{l}\text { Water } \\
\text { content }\end{array}$ & $\begin{array}{l}\text { Dry conditions decrease the } \\
\text { rhizobia population thus reduce } \\
\text { nitrogen fixation. Pronounced } \\
\text { drying-wetting cycles are also }\end{array}$ & $\begin{array}{c}\text { Albrecht et al., 1984; Kozlowski, 1976; } \\
\text { Sellstedt et al., 1993; Sinclair et al., } \\
\text { 1987. }\end{array}$ & $(-)$ & & $(+)$ & $(-)$ \\
\hline
\end{tabular}




\section{\begin{tabular}{|l|l|}
\hline & unfavorable to fixation.
\end{tabular}}

Differences between irrigation techniques (in this paper, FI: flood irrigation, SI: sprinkler irrigation, DI: drip irrigation, SDI: subsurface drip irrigation) in water amounts and delivery are likely to have temporary thermal effects thus to influence nitrogen fixation. Fixation occurs only in appropriate, medium aeration and water stress conditions (Albrecht et al., 1984), which makes high water contents and the occlusion of soil micropores adverse conditions for nitrogen fixation. By contrast, the pronounced drying/wetting cycles and especially the rather dry conditions typical of SI are said favorable to nitrification, thus to the production of enough nitrates to inhibit nodulation (Kozlowski, 1976). This confirms a more general trend that high nitrates contents (possibly emanating from an independent source, as mineral fertilization) decreases the efficiency of symbiotic fixation (Muthukumarasamy et al., 1999, Thorburn et al., 2003a). The nearly-saturated conditions taking place immediately after the peak water content under SI have also been reported to induce a flash of microbial activity which enhances denitrification (Laher and Avnimelech, 1980) thus also creates unfavorable conditions for fixation. Under SDI, the existence of water stress at low water contents in the upper soil layer may affect the symbiosis between legumes and rhizobia: the fixation of atmospheric nitrogen becomes less efficient, the population of nodules is reduced and so is the nitrogenase activity (Sellstedt et al., 1993; Sinclair et al., 1987). By contrast, the frequent water application in DI maintains soil humidity at a level favorable for nitrogen fixation.

From literature, a significant interplay seems to exist between (i) the irrigation technique, (ii) nitrification and mineralization with effects on soil $\mathrm{pH}$ and (iii) fixation as influenced by soil $\mathrm{pH}$ (thus indirectly by the cited nitrogen transformations). Soil acidification is caused by the nitrification of excess fertilizers, which lowers soil pH (Han et al., 2015; Malhi et al., 1998). Nitrification and mineralization rates are controlled by microbial activity which in turn is typically related to soil temperature and water content (Colaizzi et al., 2004; Kozlowski, 1976). The various irrigation techniques have specific effects on soil moisture content and temperature fields, thus expectedly on nitrification and mineralization rates, then in turn on soil $\mathrm{pH}$ and on nitrogen fixation. For example, the saturated or nearly-saturated conditions found below FI and SI inhibit nitrification thus decrease soil $\mathrm{pH}$ and nitrogen fixation (Haynes and Swift, 1987; Parchomchuk et al., 1993). Under DI, the nitrification rate decreases in the vicinity of the emitter but nitrification still occurs outside the saturated 
domain. By contrast, water application through SDI enables higher $\mathrm{pH}$ values near the soil surface than under DI (Bora and Ray, 2015). Other literature sources (e.g. Kumar and Shivay, 2008) suggest that soils tend to be more acidic under FI or SI due to higher leaching of the bases though this likely depends on soil's parent material and organic content. The reported case is that of basic elements held by soil colloids and organic matter, which leave the exchange sites on the clay particles through crop uptake or leaching, to be replaced by the hydrogen ions. As less water is generally used for DI and SDI, the expected trend is that less basic elements will be replaced, resulting in more fixation.

A consensus exists on the adverse effects of salinity on nitrogen fixation, either from the phenomenological point of view (e.g. Lindström et al., 1985; on Rhizobium behavior) or in studies dedicated to specific crop varieties (e.g. Berstein and Ogata, 1966; for soybean and alfalfa, Garg and Chandel, 2011; for Cajanis Cajan, Hafeez et al., 1988; for Vigna Radiata or Rao et al., 2002; and Soussi et al., 1998; for chickpea). The cases of agricultural (SanchezDiaz et al., 1982) and tropical soils (Silva and Uchida, 2000) have been handled. Microirrigation for crop production (Lamm et al., 2007) and some modern challenges of "saline agriculture" (Bruning and Rozema, 2013) have also been recently addressed.

As for salinity, the role of temperature on nitrogen fixation (and on most of nitrogen transformations) is well know from thermodynamics (energy of activation) and has been widely documented, for various species (e.g. Bell et al., 1998; for Lettuce, Colaizzi et al., 2004; for cotton and Lü et al., 2015; for winter wheat) and experimental conditions (e.g. Bordeleau and Prévost, 1994; and Zahran, 1999; for semi-arid contexts or Rice et al., 1995; for low root temperature).

\subsection{Nitrogen mineralization}

\subsubsection{Basics of nitrogen mineralization}

The gross $\mathrm{N}$-mineralization is the decomposition of large organic nitrogen molecules (proteins, amino sugars and amino acids present in organic matter, plant residuals or organic manure, noted $\mathrm{R}-\mathrm{NH}_{2}$ in Fig.1) into inorganic nitrogen by heterotrophic bacteria using carbon as their source of energy. Mineralization produces ammonium $\left(\mathrm{NH}_{4}{ }^{+}\right.$, Ammonification in Eq.3) which is then converted to nitrate $\left(\mathrm{NO}_{3}{ }^{-}\right)$by Nitrification (Eq.4). 


$$
\begin{aligned}
& \mathrm{NH}_{3}+\mathrm{H}_{2} \mathrm{O} \leftrightarrow \mathrm{NH}_{4}^{+}+\mathrm{OH}^{-} \\
& \mathrm{NH}_{4}^{+} \rightarrow \mathrm{NO}_{2}^{-} \rightarrow \mathrm{NO}_{3}^{-}
\end{aligned}
$$

These two forms allow nitrogen uptake by plants roots. Immobilization (also organization or reorganization) is the adverse process, consisting for example in the oxidation of carbonic substrates. The difference between the nitrogen amount that issues from gross $\mathrm{N}$ mineralization and that organized by soil microorganisms is the net mineralization depending on the activity or inactivation of the heterotrophic bacteria.

\subsubsection{Influence of the irrigation technique on nitrogen mineralization}

Table 2 lists the soil variables (soil $\mathrm{C} / \mathrm{N}$ ratio, $\mathrm{pH}$, salinity, temperature, texture and water content, by alphabetical order) that control nitrogen mineralization or immobilization, with the suggested influence of the irrigation techniques (nitrogen immobilization is the subject of the next subsection), mainly through their effects on soil water content.

Table 2 - Soil variables that control nitrogen mineralization or immobilization, with the expected influence of the irrigation technique (FI: flood irrigation, SI: sprinkler irrigation, DI: drip irrigation, SDI: subsurface drip irrigation). Besides additional comments, this influence is noted (+) for "favorable", (-) for "unfavorable" while (0) indicates "no

\begin{tabular}{|c|c|c|c|c|c|c|}
\hline \multicolumn{3}{|c|}{ Data } & \multicolumn{4}{|c|}{ Influence on mineralization } \\
\hline Variable & Effects & References & FI & SI & DI & SDI \\
\hline $\mathrm{C} / \mathrm{N}$ & $\begin{array}{c}\mathrm{C} / \mathrm{N}<25 \text { favors } \\
\text { mineralization but } \mathrm{C} / \mathrm{N}>25 \\
\text { favors immobilization. High } \\
\text { lignin contents allow } \\
\text { mineralization for high } \mathrm{C} / \mathrm{N} \\
\text { ratios. }\end{array}$ & $\begin{array}{l}\text { Aoyama, 1991; Bengtsson et al., 2003; Fox et } \\
\text { al., 1990; Haynes, 1986; Janssen 1996, } \\
\text { Osemwota et al., 2004; Qian and Schoenau, } \\
\text { 2002; Robertson and Groffman, 2007; Sparling } \\
\text { et al., } 2015 \text {. }\end{array}$ & $\begin{array}{l}\text { Exp } \\
\text { high }\end{array}$ & & (0) & $\begin{array}{l}\text { Expected } \\
\text { lower }(+)\end{array}$ \\
\hline $\mathrm{pH}$ & $\begin{array}{l}\text { Acid soils unfavorable for } \\
\text { microorganisms and } \\
\text { mineralization. Significant } \\
\text { water movements tend to } \\
\quad \text { flush the anions. }\end{array}$ & $\begin{array}{c}\text { Cheng et al., 2013; Fu et al., 1987; Kumar and } \\
\text { Shivay, } 2008 .\end{array}$ & $\begin{array}{r}\text { Loc } \\
\text { dec } \\
\text { due to } \\
\text { water } \\
\qquad\end{array}$ & $\begin{array}{l}\mathrm{pH} \\
\text { case } \\
\text { large } \\
\text { lows }\end{array}$ & & $\begin{array}{l}\mathrm{H}_{\mathrm{DI}}<\mathrm{pH}_{\mathrm{SDI}} \\
(-) \quad(+)\end{array}$ \\
\hline Salinity & $\begin{array}{c}\text { Excessive surface } \\
\text { fertilization causes salinity } \\
\text { issues that reduce } \\
\text { mineralization. }\end{array}$ & Han et al., 2015; Rietz and Haynes, 2003. & $(0)$ & $(+)$ & (0) & $(-)$ \\
\hline
\end{tabular}
expected significant effect on the process". 
Author-produced version of the article published in Agricultural Water Management, 2016, N¹78, p. $225-238$. The original publication is available at http://www.sciencedirect.com/science/article/pii/S0378377416303833 Doi: 10.1016/j.agwat.2016.09.027

\begin{tabular}{|c|c|c|c|c|c|}
\hline $\begin{array}{c}\text { Temperature } \\
\text { (T) }\end{array}$ & $\begin{array}{l}\text { Mineralization is inactive for } \\
\quad \mathrm{T}<5^{\circ} \mathrm{C} \text {, optimal for } \\
25<\mathrm{T}<35^{\circ} \mathrm{C} \text {. } \mathrm{T} \text { is affected by } \\
\text { the irrigation technique. }\end{array}$ & $\begin{array}{l}\text { Bell et al., 1998; Colaizzi et al., 2004; Dalias et } \\
\text { al., 2002; , Lü et al., 2015; Stevenson, 1986; } \\
\text { Trasar-Cepeda et al., 2007; Wang et al., 2000. }\end{array}$ & & \multicolumn{2}{|c|}{$\begin{array}{c}\mathrm{T}_{\mathrm{FI}}<\mathrm{T}_{\mathrm{SI}}<\mathrm{T}_{\mathrm{DI}}<\mathrm{T}_{\mathrm{SDI}} \\
(-)(-)(+)(+)\end{array}$} \\
\hline Texture & $\begin{array}{l}\text { Air circulation in sandy or } \\
\text { silty soils is convenient for } \\
\text { microorganisms thus for } \\
\text { mineralization (unlike clayey } \\
\text { soils). }\end{array}$ & Hassink et al., 1993; Verberne et al. 1990. & & \multicolumn{2}{|c|}{ (0) } \\
\hline $\begin{array}{l}\text { Types of } \mathrm{N} \\
\text { molecules }\end{array}$ & $\begin{array}{l}\text { Immobilization is higher } \\
\text { with ammonia }\end{array}$ & $\begin{array}{c}\text { Azam et al., 1993; Burger and Jackson, 2003; } \\
\text { Recous et al., 1990; Vitousek and Andariese, } \\
1986 .\end{array}$ & & \multicolumn{2}{|c|}{$(0)$} \\
\hline $\begin{array}{l}\text { Water } \\
\text { content }\end{array}$ & $\begin{array}{c}\text { High } \theta \text { values favor } \\
\text { mineralization while } \\
\text { saturation or too low } \theta \\
\text { values are unfavorable. } \\
\text { However, flashes of } \\
\text { mineralization occur during } \\
\text { soil desaturation, for near- } \\
\text { saturation levels. }\end{array}$ & $\begin{array}{l}\text { Agehara and Warncke, 2005; Bengtsson et al., } \\
\text { 2003; Birch, 1958; Borken \& Matzner, 2009; } \\
\text { Cabrera, 1993; Fierer and Schimel, 2002; Fierer } \\
\text { et al., 2003; Franzluebbers, 1999; Khalil, 2008; } \\
\text { Kieft et al., 1987; Mikha et al., 2005; Miller et } \\
\text { al., 2005, Myers et al., 1982; Neve and Hofman } \\
\text { 2002, Osemwota et al., 2004; Ouyang and Li, } \\
\text { 2013; Pulleman and Tietema, 1999; Sierra, } \\
\text { 1997; Skopp et al. 1990; Thorburn et al., 2003; } \\
\text { Valé et al., 2007; Wang et al., 2001; Xiang et al., } \\
\text { 2008. }\end{array}$ & $(-)$ & $(+)$ & $(-)$ \\
\hline
\end{tabular}

Mineralization was found optimum in presence of enough water in soil pores (Cabrera, 1993; Fierer and Schimel, 2002; Valé et al., 2007) either close to field capacity (Myers et al., 1982; Osemwota et al., 2004) or for water contents between 65 and $75 \%$ of it (Agehara and Warncke, 2005) when the near-saturation and saturation states were thought to decrease mineralization as they deprive soil microorganisms of the oxygen they need (Borken and Matzner, 2009; Neve and Hofman, 2002; Skopp et al., 1990). By contrast, soil microorganisms show a minimal level of activity for severe water depletion though mineralization has not been reported to completely cease, even near the permanent wilting point (Neve and Hofman, 2002; Sierra, 1997). An expected corollary is that the combined water content and aeration conditions convenient for mineralization are more easily met in rather coarse soils than in clayey soils (e.g. Hassink et al., 1993; Verberne et al., 1990) which outlines the possible effect of soil texture (plausibly a second-order effect though, or only to be considered in conjunction with the influence of the irrigation techniques on water content). 
Author-produced version of the article published in Agricultural Water Management, 2016, N¹78, p. $225-238$.

The original publication is available at http://www.sciencedirect.com/science/article/pii/S0378377416303833

Doi: 10.1016/j.agwat.2016.09.027

Precisely, the frequent application of relatively small amounts of water is characteristic of DI and aims at maintaining soil water contents compatible with easy root water uptake. This, in turn, ensures humidity conditions favorable for microbial activity and mineralization (Khalil, 2008; Thorburn et al., 2003b). On the contrary, the less frequent applications of far higher water amounts result in high-magnitude perturbations of soil moisture conditions, in the form of severe drying-wetting cycles, whose extreme water content values are both reported adverse to mineralization (Thorburn et al., 2003a, b). However, "flashes of mineralization" have been observed during the drying-wetting cycles of sprinker irrigation (Birch 1958, Fierer and Schimel, 2002; Fierer et al., 2003; Franzluebbers 1999, Mikha et al., 2005) and related to sharp increases in the number and activity of microorganisms, during short time intervals following the peak in water content. Several hypotheses have been put forward to explain these flashes.

- Very low water contents induce very strong matric potentials for which microbial activity is drastically reduced: soil microorganisms accumulate organic and non-organic solutes in their cells to balance the local matric potential conditions. The next moisture increase (irrigation or precipitation) causes the quick release of most of these trapped solutes into the soil solution, leading to this "flash of mineralization" or "mineralization pulse" (Fierer et al., 2003; Xiang et al., 2008).

- A complementary explanation invokes the perturbation of soil aggregates by the drying-wetting cycles. The mechanical effects of quick and intense moisture increases likely leads to the release of the organic matter trapped in the macro and micro soil aggregates. This increase would also be responsible for the desorption of the organic matter from clayey soil horizons (Bengtsson et al., 2003; Franzluebbers, 1999; Kieft et al., 1987; Miller et al., 2005; Ouyang and Li, 2013).

The $\mathrm{C} / \mathrm{N}$ ratio, i.e. carbon mass divided by nitrogen mass, directly acts upon the mineralization, immobilization and nitrification of soil nitrogen. Low $\mathrm{C} / \mathrm{N}$ ratios $(\mathrm{C} / \mathrm{N}<25)$ favor mineralization through their high mineral nitrogen content while high $\mathrm{C} / \mathrm{N}$ ratios $(\mathrm{C} / \mathrm{N}>25)$ enhance nitrogen immobilization by microorganisms. This negative correlation between $\mathrm{C} / \mathrm{N}$ ratios and mineralization has been widely observed (Bengtsson et al., 2003; Janssen, 1996; Qian and Schoenau, 2002) though plants with high lignin content may exhibit non-negligible mineralization rates even at high $\mathrm{C} / \mathrm{N}$ ratios (e.g. Aoyama, 1991). However, the degradation of lignin into polyphenols reduces mineralization as these assemble into 
Author-produced version of the article published in Agricultural Water Management, 2016, №178, p. 225-238.

The original publication is available at http://www.sciencedirect.com/science/article/pii/S0378377416303833

Doi: 10.1016/j.agwat.2016.09.027

complex forms with plant proteins and amino-acids. In such cases, lignin content is often used as a proxy for mineralization besides or instead of the $\mathrm{C} / \mathrm{N}$ ratio (Fox et al., 1990; Osemwota et al., 2004). In complement, a positive correlation has been outlined between the nitrogen concentration in plants prior to their burying in soils and the mineralization rates subsequently obtained (Haynes, 1986) in absence of any strong concentration in lignin or polyphenols (Fox et al., 1990, Osemwota et al. 2004, Stevenson, 1986). The cited literature suggests that the expected $\mathrm{C} / \mathrm{N}$ ratio tends to be lower under SDI than under DI, SI and FI because SDI induces lower water contents in the superficial soil horizons where most of microbial activity takes place. This is a consequence possibly drawn (though extrapolated) from differences in $\mathrm{C} / \mathrm{N}$ ratios observed (Sparling et al., 2015) between irrigated and non-irrigated soils.

Besides the $\mathrm{C} / \mathrm{N}$ ratio, the nitrogen dose applied is expected to have an effect on soil pH and salinity also (Han et al., 2015), thus on mineralization too. This effect varies with the positioning of the fertilizer: salinity issues appear when using SI and surface fertilizers, possibly reducing the microbial activity. Conversely, the injection of fertilizers in solution with SDI is less prone to reduce the microbial activity (Rietz and Haynes, 2003). Variations in the $\mathrm{pH}$ of soil solution also control mineralization, the optimal level being neutral or slightly basic, as acidity is clearly unfavorable to microbial activity thus to mineralization (Cheng et al., 2013; Fu et al., 1987).

Soil temperature also exerts a strong control on microbial activity, thus on mineralization, often said maximal between 25 and $35^{\circ} \mathrm{C}$. The doubling of microbial activity for any $10^{\circ} \mathrm{C}$-increase above $5^{\circ} \mathrm{C}$ has been reported (Dalias et al., 2002; Trasar-Cepeda et al., 2007) as well as the existence of the $5^{\circ} \mathrm{C}$-threshold under which mineralization cannot take place (Stevenson, 1986). These elements are coherent with the expected increase of activity of the enzymes involved in the degradation of organic matter for temperatures between 30 and $50^{\circ} \mathrm{C}$ (e.g. Guntinas et al., 2012). As previously said, the irrigation method very likely affects soil physical properties such as the soil temperature (Lü et al., 2015) and a paper mentions field conditions in which the monitored soil temperature was most often higher for DI than for SI which ensures more favorable conditions for mineralization (Wang et al., 2000). Evett et al. (2005) reported smaller soil temperature fluctuations and warmer near-surface temperatures for SDI than for DI, attributing the observed differences to stronger evapotranspiration rates (and the associated cooling effect) under DI than SDI, owing to 
higher average water contents. Again, the extrapolation to other irrigation techniques seem possible, resulting in $\mathrm{T}_{\mathrm{FI}}<\mathrm{T}_{\mathrm{SI}}<\mathrm{T}_{\mathrm{DI}}<\mathrm{T}_{\mathrm{SDI}}$, in coherence with Bell et al. (1998) and Colaizzi et al. (2004).

Soil texture is also known to influence mineralization processes: sandy soils and silts a priori favor mineralization because their aerated structure is prone to ensure sufficient oxygen availability for soil microorganisms. By contrast, clayey soils tend to prevent air circulation thus to inactivate mineralization processes. Moreover, the sorption of organic matter on clay particles or sheets reduces its availability for mineralization (Hassink et al., 1993; Verberne et al. 1990).

\subsection{Nitrogen immobilization}

\subsubsection{Basics of nitrogen immobilization}

Immobilization is the uptake of mineral nitrogen by microorganisms to synthesize their tissue and develop their own populations. The $\mathrm{C} / \mathrm{N}$ ratio is often said to decide which one of the immobilization or mineralization prevails over the other (Bengtsson et al., 2003, Robertson and Groffman, 2007) and immobilization will likely be the dominant process in the soils with a high $\mathrm{C} / \mathrm{N}$ ratio. Besides the irrigation technique, the type and amount of plant residue left on the soil surface or buried in the soil after harvesting is thus expected to decide whether immobilization prevails or not. For example, wheat straw or corn stalks plowed under may stimulate the microbial activity which uses the available nitrogen in soil for decaying plant material. So, immobilization will be the dominant process and will stop once the plant residue has become highly decayed. In contrast, mineralization will directly take place when a legume crop is buried (Dinnes et al., 2002).

\subsubsection{Influence of the irrigation technique on nitrogen immobilization}

The gross immobilization rate was found between 18 and $119 \mathrm{mg} \mathrm{N}$ per soil kilogram and per day in drying-rewetting soils reproducing the conditions of SI (Bengtsson et al., 2003; Pulleman and Tietema, 1999). Other results showed that the immobilization was greater in aerobic conditions (DI or SDI) than under flooded soils (furrow irrigation, Wang et al., 2001). 
Finally, immobilization was often found greater when ammonium $\left(\mathrm{NH}_{4}{ }^{+}\right)$fertilizers are applied (Burger and Jackson, 2003; Recous et al., 1990; Vitousek and Andariese, 1986; in Table 2) probably because ammonium is preferred to nitrates $\left(\mathrm{NO}_{3}{ }^{-}\right)$for assimilation by the microorganisms when the two forms are present (Azam et al., 1993).

\subsection{Nitrification}

\subsubsection{Basics of nitrification}

Nitrification is the biological oxidation of ammonium $\left(\mathrm{NH}_{4}^{+}\right)$in nitrates $\left(\mathrm{NO}_{3}{ }^{-}\right)$under the successive actions of Nitrosomonas bacteria (nitritation stage, $\mathrm{NH}_{4}^{+}$to $\mathrm{NO}_{2}{ }^{-}$) and bacteria of the Nitrobacter genus (nitratation stage, $\mathrm{NO}_{2}^{-}$to $\mathrm{NO}_{3}^{-}$, see Fig.1), in the following sequences:

$$
\begin{aligned}
& \mathrm{NH}_{4}^{+}+\mathrm{O}_{2} \stackrel{\text { Nitrosomonas }}{\longrightarrow} \mathrm{NO}_{2}^{-}+\mathrm{H}_{2} \mathrm{O}+\mathrm{H}^{+}+\mathrm{e}^{-} \\
& \mathrm{NO}_{2}^{-}+\mathrm{O}_{2} \stackrel{\text { Nitrobacter }}{\longrightarrow} \mathrm{NO}_{3}^{-}+\mathrm{e}^{-}
\end{aligned}
$$

This makes nitrogen available for plants and microbes, but also prone to lixiviation or denitrification losses (Arp et al., 2002; Klotz, 2011; Sahrawat 1982). Nitrification is either autotrophic or heterotrophic, depending on the bacteria and fungi at play.

- Autotrophic nitrification is performed by bacteria that draw their energy from one of the two stages of the oxidation of ammonium into nitrates (Verstraete and Focht, 1997). Bacteria taking part in the first, nitritation stage are categorized as ammonia-oxidizing bacteria, e.g. Nitrosomonas, Nitrosococcus, Nitrosolobus and Nitrosovibrio. Bacteria involved in the second, nitratation stage belong to the nitrite-oxidizing category, e.g. Nitrobacter and Nitrospira (De Boer and Kowalchuk, 2001, Treusch et al., 2005).

- Heterotrophic nitrification is due to a wide range of fungi and heterotrophic bacteria unable to develop on inorganic grounds, needing organic compounds to synthesize their tissue. Heterotrophic nitrification is generally less than autotrophic nitrification though nonnegligible in acid soils (Addiscott et al., 2005). 
Author-produced version of the article published in Agricultural Water Management, 2016, N¹78, p. $225-238$.

The original publication is available at http://www.sciencedirect.com/science/article/pii/S0378377416303833

Doi: 10.1016/j.agwat.2016.09.027

\subsubsection{Influence of the irrigation techniques on nitrification}

Table 3 lists the soil variables (soil $\mathrm{C} / \mathrm{N}$ ratio, $\mathrm{pH}$, temperature and water content, by alphabetical order) that control nitrification, with the suggested influence of the irrigation techniques, mainly through their effects on soil water content.

Table 3 - Soil variables that control nitrification, with the expected influence of the irrigation technique (FI: flood irrigation, SI: sprinkler irrigation, DI: drip irrigation, SDI: subsurface drip irrigation). Besides additional comments, this influence is noted (+) for "favorable", (-) for "unfavorable" while 0 indicates "no expected significant effect on the process".

\begin{tabular}{|c|c|c|c|c|c|c|}
\hline \multicolumn{3}{|c|}{ Data } & \multicolumn{4}{|c|}{ Influence on nitrification } \\
\hline Variable & Effects & References & FI & SI & DI & SDI \\
\hline $\mathrm{C} / \mathrm{N}$ & $\begin{array}{c}\text { High } \mathrm{C} / \mathrm{N} \text { ratios decrease } \\
\text { nitrification rates. }\end{array}$ & $\begin{array}{l}\text { Bengtsson et al., 2003; Gundersen et al., } \\
\text { 1998; Persson et al., 2000; Ross et al., 2004; } \\
\text { Sparling et al., } 2015 .\end{array}$ & \multicolumn{2}{|c|}{$\begin{array}{l}\text { Expected } \\
\text { higher (-) }\end{array}$} & $(0)$ & $\begin{array}{l}\text { Expected } \\
\text { lower }(+)\end{array}$ \\
\hline $\mathrm{pH}$ & $\begin{array}{c}\text { Neutral or slightly alkaline soils } \\
\text { favor nitrification that may also } \\
\text { occur in acid soils. Significant } \\
\text { water movements tend to flush } \\
\text { the anions. }\end{array}$ & \begin{tabular}{|c|} 
Bengtsson et al., 2003; De Boer and \\
Kowalchuk, 2001; Dommergues et al., \\
1978; Kumar and Shivay, 2008; Persson and \\
Wiren, 1995; Sahrawat, 1982; Simek and \\
Cooper, 2002; Verstraete and Focht, 1977.
\end{tabular} & \multicolumn{2}{|c|}{$\begin{array}{l}\text { Local } \mathrm{pH} \\
\text { decrease due } \\
\text { to large water } \\
\text { flows (-) }\end{array}$} & \multicolumn{2}{|c|}{$\begin{array}{c}\mathrm{pH}_{\mathrm{DI}}<\mathrm{pH}_{\mathrm{SDI}} \\
(-) \quad(+)\end{array}$} \\
\hline $\begin{array}{l}\text { Temperature } \\
\text { (T) }\end{array}$ & \begin{tabular}{|c|} 
Optimal nitrification for \\
$25<\mathrm{T}<35^{\circ} \mathrm{C} . \mathrm{T}$ is affected by the \\
irrigation technique.
\end{tabular} & $\begin{array}{l}\text { Bell et al., 1998; Colaizzi et al., 2004; } \\
\text { Haynes, 1986; Lü et al., 2015; Malhi and } \\
\text { McGill, } 1982 .\end{array}$ & \multicolumn{4}{|c|}{$\begin{array}{c}\mathrm{T}_{\mathrm{FI}}<\mathrm{T}_{\mathrm{SI}}<\mathrm{T}_{\mathrm{DI}}<\mathrm{T}_{\mathrm{SDI}} \\
(-)(-)(+)(+)\end{array}$} \\
\hline $\begin{array}{l}\text { Water } \\
\text { content }\end{array}$ & $\begin{array}{l}\text { Nitrification occurs at low water } \\
\text { contents. Drying-wetting cycles } \\
\text { are }{ }^{[1]} \text { favorable or }{ }^{[2]} \text { unfavorable. }\end{array}$ & $\begin{array}{l}{ }^{[1]} \text { Brockwell and Whalley, } 1970 ;{ }^{[1]} \text { Fierer } \\
\text { and Schimel, 2002; }{ }^{[2]} \text { Franzluebbers, } 1999 ; \\
\text { Laher and Avnimelech, 1980; Malhi and } \\
\quad \text { McGill, 1982; Zaman et al. } 1999 .\end{array}$ & $(-)$ & $(+)$ & $(-)$ & $(+)$ \\
\hline
\end{tabular}

The marked wetting and drying cycles in areas of infrequent precipitation or in SI could lead to enhanced nitrification (Brockwell and Whalley, 1970) as nitrification requires aerobic conditions. Conversely, the lack of oxygen for saturated or near-saturated soils after rainfall or irrigation events potentially takes nitrification down to zero (Laher and Avnimelech, 1980) while significant nitrification rates have been found for very high absolute matric potentials of the order of $-33 \mathrm{kPa}$ (Malhi and McGill, 1982). This may seem surprising given that nitrifiers are generally considered to be highly sensitive to water stress. A controversy therefore exists regarding the effect of the repeated drying-wetting cycles on 
Author-produced version of the article published in Agricultural Water Management, 2016, №178, p. 225-238.

The original publication is available at http://www.sciencedirect.com/science/article/pii/S0378377416303833

Doi: 10.1016/j.agwat.2016.09.027

nitrification. Such cycles have been reported as unfavorable (Franzluebbers et al., 1994) or favorable (Fierer and Schimel, 2002) in a study with two frequently stressed loam and clayloam soils, due to a significant increase in the autotrophic nitrifier populations.

A negative correlation has often been stated between the values of the $\mathrm{C} / \mathrm{N}$ ratio and nitrification rates (Bengtsson et al., 2003; Gundersen et al., 1998; Persson et al., 2000; Ross et al., 2004). For example, this negative relationship resulted in an increase in the nitrification rate from 11.62 to $14.18 \mathrm{mg} \mathrm{N}$ per soil kilogram and per day when the $\mathrm{C} / \mathrm{N}$ ratio decreased from 20 to 10 at temperatures between 18 and $22^{\circ} \mathrm{C}$ in batch reactors in a study by Feng et al. (2011). The availability of ammonium for nitrification depends first on the intensity of root water and nitrogen uptake, seen as a sink term (Bengtsson et al., 2003; Robertson and Groffman, 2007; Verhagen et al., 1995). In coherence, the burying of crop residuals with high $\mathrm{C} / \mathrm{N}$ ratios stimulates the microbial activity thus increases the consumption of ammonia, which in turn reduces nitrification (Robertson and Groffman, 2007).

The pH values between 6.5 and 8 have been reported optimal (Persson et al., 2000; Sahrawat, 1982; Sainte-Marie and Paré, 1999) and no autotrophic nitrification is supposed to occur at $\mathrm{pH}<4.5$ because of the exponential decrease of available ammonia (De Boer and Kowalchuk, 2001). However, another study showed the ability of the autotrophic nitrifying bacteria to nitrify at a high rate, with $5.6 \mathrm{~g}$ of nitrogen oxidized per liter of soil solution and per day, at a low $3.2 \mathrm{pH}$, even with a negligible free ammonia concentration of around 10 $\mathrm{mg} \mathrm{L}^{-1}$ (Tarre and Green, 2004). Other authors have suggested that the nitrification for similar low $\mathrm{pH}$ values depend on the existence of microsites of high $\mathrm{pH}$ in acid soils (Rose and Tempest, 1989) or on the presence of biofilms or aggregates, where organisms may be protected against acidity (Boer et al., 1991). As previously mentioned, heterotrophic nitrification may also take place at low pH values (Dommergues et al., 1978; Brierley et al., 2001).

In complement, an increase in soil temperature acts in the expected positive way on nitrification rates (Haynes, 1986) as on the other nitrogen transformations (Bell et al., 1998; Colaizzi et al., 2004; Lü et al., 2015). For example, an incubation experiment involving three soils at $-33 \mathrm{kPa}$ and an increase in temperature from 4 to $20^{\circ} \mathrm{C}$ resulted in an increase of nitrification rates from $0.82 \mu \mathrm{g} \mathrm{N} \mathrm{g}^{-1}$ day $^{-1}$ to $3.31 \mu \mathrm{g} \mathrm{N} \mathrm{g}^{-1}$ day $^{-1}$ (Malhi and McGill, 1982). 


\section{Influence of the irrigation techniques on nitrogen fluxes}

\subsection{Losses by denitrification}

\subsubsection{Basics of denitrification}

Denitrification designates the reduction of nitrates $\left(\mathrm{NO}_{3}{ }^{-}\right)$that leads to gaseous compounds mainly from the action of anaerobic bacteria, in the following sequence (Ferguson, 1994; Knowles, 1982; Robertson and Groffman, 2007):

$$
\mathrm{NO}_{3}^{-} \rightarrow \mathrm{NO}_{2}^{-} \rightarrow \mathrm{NO} \rightarrow \mathrm{N}_{2} \mathrm{O} \rightarrow \mathrm{N}_{2}
$$

Most denitrifying bacteria are heterotrophic, e.g. Paracoccus denitrificans, while only a few are autotrophic, e.g. Thiobacillus denitrificans (Rivett et al., 2008).

\subsubsection{Influence of the irrigation technique on denitrification}

Table 4 lists the soil variables (soil $\mathrm{pH}$, temperature, texture and water content, by alphabetical order) that control denitrification, with the suggested influence of the irrigation techniques, mainly through their effects on soil water content.

Table 4 - Soil variables that control denitrification, with the expected influence of the irrigation technique (FI: flood irrigation, SI: sprinkler irrigation, DI: drip irrigation, SDI: subsurface drip irrigation). Besides additional comments, this influence is noted (+) for "favorable", (-) for "unfavorable" while (0) indicates "no expected significant effect on the process".

\begin{tabular}{|c|c|c|c|c|c|}
\hline \multicolumn{3}{|c|}{ Data } & \multicolumn{3}{|c|}{$\begin{array}{l}\text { Influence on } \\
\text { denitrification }\end{array}$} \\
\hline Variable & Effects & References & SI & DI & SDI \\
\hline $\mathrm{pH}$ & $\begin{array}{c}\text { Optimal range: } 7<\mathrm{pH}<8 \text {. } \\
\text { Significant water movements tend } \\
\text { to flush the anions. }\end{array}$ & $\begin{array}{l}\text { Bremner and Shaw, 1958; Kumar and Shivay, } \\
\text { 2008; Parkin et al., 1985; Sahrawat and } \\
\text { Keeney, 1986; Wijler and Delwiche, } 1954 .\end{array}$ & $\begin{array}{l}\text { Local } \mathrm{pH} \\
\text { decrease due to } \\
\text { large water } \\
\text { flows (-) }\end{array}$ & & (0) \\
\hline $\begin{array}{l}\text { Temperature } \\
\text { (T) }\end{array}$ & $\begin{array}{l}\text { Positive relationship and optimal } \\
\text { denitrification for } 25<\mathrm{T}<35^{\circ} \mathrm{C} \text {. } \mathrm{T} \text { is } \\
\text { affected by the irrigation technique. }\end{array}$ & $\begin{array}{l}\text { Bell et al., 1998; Bremner and Shaw 1958, } \\
\text { Colaizzi et al., 2004; De Klein and Van } \\
\text { Logtestijn, 1996; Lü et al., 2015; Stanford et } \\
\text { al., 1975. }\end{array}$ & $\begin{array}{l}\mathrm{T}_{\mathrm{FI}}<\mathrm{T}_{\mathrm{SI}}<\mathrm{T}_{\mathrm{DI}} \\
(-)(-)(+)\end{array}$ & & \\
\hline Texture & $\begin{array}{l}\text { Fine-textured soils favor anaerobic } \\
\text { conditions thus denitrification. }\end{array}$ & Aulakh et al., 1991; Gilliam et al., 1978.. & (0) & & \\
\hline
\end{tabular}


Author-produced version of the article published in Agricultural Water Management, 2016, №178, p. $225-238$.

The original publication is available at http://www.sciencedirect.com/science/article/pii/S0378377416303833

\begin{tabular}{|c|c|c|c|c|}
\hline $\begin{array}{l}\text { Water } \\
\text { content }\end{array}$ & $\begin{array}{l}\text { Global or local high } \theta \text { and } \\
\text { anaerobic conditions favor } \\
\text { denitrification. Drying- wetting } \\
\text { cycles favor denitrification. }\end{array}$ & $\begin{array}{c}\text { Burford and Bremner, 1975; Davidson, 1992; } \\
\text { Ferguson, 1994; Germon and Couton, 1999; } \\
\text { Laher and Avnimelech, 1980; Robertson and } \\
\quad \text { Groffman, 2007; Valé et al., } 2007 .\end{array}$ & $(+)$ & $(-)$ \\
\hline
\end{tabular}

Denitrification preferentially occurs in the local anaerobic or global weakly-aerobic conditions associated with average saturation indices of at least 60\% (Burford and Bremner, 1975; Ferguson, 1994; Germon and Couton, 1999; Robertson and Groffman 2007). The already mentioned flash of microbial activity for mineralization, that follows the peak in water content during the drying-wetting cycle under SI, was also found prone to increase denitrification (Davidson, 1992; Laher and Avnimelech, 1980; Valé, 2006; Valé et al., 2007). By contrast, the frequent application of limited water doses within DI dictates aerobic conditions, relatively far from soil saturation, that tend to limit denitrification, also when compared to border irrigation (e.g. Sanchez-Martin et al., 2008). One step further, direct observations (Suddick et al., 2011) have recently shown that $\mathrm{N}_{2} \mathrm{O}$ emissions associated with fertigation were weaker for SDI than for DI. The most conventional irrigation techniques (SI, border irrigation) create soil regions (micro-sites) with local anaerobic conditions, thus enhancing nitrogen losses by denitrification (Burger et al., 2005; Kennedy et al., 2013; Sanchez-Martin et al., 2008).

Many early works (Bremmer \& Shaw, 1958; Parkin et al., 1985, Sahrawat and Keeney, 1986; Wijler and Delwiche, 1954) showed that neutral alkaline conditions $(6<\mathrm{pH}<8)$ enhanced denitrification rates, demonstrating very low rates roughly for $\mathrm{pH}<5$ and maximal rates for $\mathrm{pH}$ values between 7 and 8 . The effects of soil texture on denitrification rates have been explored, to the conclusion that fine soils, that impede water flow, are likely associated with higher denitrification rates than coarse soils (Aulakh et al., 1991; Gilliam et al., 1978,). In other words, for a given soil texture, especially for fine soils, the irrigation techniques associated with saturated conditions are more likely to induce denitrification. In complement, the positive relationship between denitrification and temperature is also well known: the process halts at low positive temperatures and needs temperatures above 20 to $25^{\circ} \mathrm{C}$ to become really active (Bailey, 1976; De Klein \& Van Logtestijn, 1996; Stanford et al. 1975). 


\subsection{Losses by runoff, volatilization and lixiviation}

\subsubsection{Nitrogen losses by runoff and volatilization}

Nitrogen losses are well-documented terms of the nitrogen cycle and budget, being in direct line with the major environmental issue of surface and groundwater contamination. The reduction of nitrogen losses is a recognized agricultural and economic challenge: to ensure the maximum efficiency of nitrogen applications within sustainable site-preserving practices, techniques and strategies (e.g. Darwish et al., 2003; Li et al., 2004; Schepers et al., 1995; Wang et al. 2001). However, at the level of details suitable for this review, nitrogen losses by runoff and volatilization have less complex and numerous determinants than nitrogen losses by lixiviation. The reader is referred to Carpenter et al. (1998) and references therein for an overview on nonpoint source pollution of surface waters by runoff. Nitrogen volatilization may originate in any ammonium-based fertilizer but urea fertilizers are more prone to volatilization because the hydrolysis of urea increases soil $\mathrm{pH}$, which in turn favors ammonia volatilization as following reactions:

$$
\begin{aligned}
& \text { Urea + Water } \stackrel{\text { Urease }}{\longrightarrow} \mathrm{NH}_{4}^{+} \\
& \mathrm{NH}_{4}^{+}+\mathrm{OH}^{-} \stackrel{\mathrm{pH} \gg 7}{\longrightarrow} \mathrm{NH}_{3}+\mathrm{H}_{2} \mathrm{O}
\end{aligned}
$$

Soil $\mathrm{pH}$ progressively increases a few days after urea application on the soil surface, resulting from the conversion of ammonium to dissolved ammonia, the later available for volatilization. Losses are higher when fertilizers (urea) are placed on the soil surface with no subsequent (or too weak) irrigation or rainfall. The choice of SI immediately after nitrogen application minimizes the losses by volatilization (Viero et al., 2015) and does not induce runoff risks (unlike FI). Urea should be applied for soil temperatures at or below $10^{\circ} \mathrm{C}$ to ensure low activity of soil microorganisms (Cameron et al., 2013) even if soil water content, not temperature, is the most critical factor said to affect ammonia volatilization (Al-Kanani et al., 1991). Finally there is an interplay between volatilization, runoff and lixiviation: volatilization is minimum when the soil is at or near saturation (i.e. above field capacity) which enhances the conversion of urea to ammonium but also expectedly triggers runoff and drainage, thus lixiviation (Murrell and Snyder, 2006). 


\subsubsection{Nitrogen losses by lixiviation}

Table 5 lists the variables (fertilizer location, scheduling of nitrogen applications, soil texture, types of nitrogen molecules and soil water content, by alphabetical order) that control lixiviation, with the suggested influence of the irrigation techniques.

Table 5 - Soil variables and nitrogen management options that control lixiviation, with the expected influence of the irrigation technique (FI: flood irrigation, SI: sprinkler irrigation, DI: drip irrigation, SDI: subsurface drip irrigation). Besides additional comments, this influence is noted (+) for "favorable", (-) for "unfavorable" while (0) indicates "no expected significant effect on the process".

\begin{tabular}{|c|c|c|c|c|c|}
\hline \multicolumn{3}{|r|}{ Data } & \multicolumn{3}{|c|}{$\begin{array}{l}\text { Influence on } \\
\text { lixiviation }\end{array}$} \\
\hline Variable & Effects & References & FI & SI $\mid \mathrm{DI}$ & SDI \\
\hline Fertilizer location & $\begin{array}{l}\text { Applications in the root } \\
\text { growth domain reduce } \\
\text { lixiviation. }\end{array}$ & $\begin{array}{l}\text { Gardenäs et al., 2005; Haynes, 1985; Siyal et al., 2012; Wiesler } \\
\text { and Itorst, } 1994 .\end{array}$ & & $(+)$ & $(-)$ \\
\hline $\begin{array}{l}\text { Scheduling of } \mathrm{N} \\
\text { applications } \\
\text { within irrigation } \\
\text { events }\end{array}$ & $\begin{array}{l}\text { Fertigation late in the } \\
\text { irrigation events } \\
\text { reduces lixiviation. }\end{array}$ & Gärdenäs et al., 2005; Hanson et al., 2006. & $(+)$ & $\begin{array}{c}\text { Contr } \\
\text { the tim } \\
\text { ) }\end{array}$ & ol on \\
\hline $\begin{array}{l}\text { Scheduling of } \mathrm{N} \\
\text { applications } \\
\text { within cropping } \\
\text { seasons }\end{array}$ & $\begin{array}{l}\text { Dose splitting and/or } \\
\text { applications during } \\
\text { strong crop growth } \\
\text { drastically reduce } \\
\text { lixiviation. }\end{array}$ & $\begin{array}{l}\text { Cote et al., 2003; Dinnes et al., 2002; Gallais and Hirel, 2004; } \\
\text { Gärdenäs et al., 2005; Hanson et al. 2006; Hassan et al., 2010; } \\
\text { Jokela and Randall, 1989; Li et al., 2005; Mmolawa and Or, } \\
\text { 2000; Prunty and Greenland, 1997; Randall and Sawyer, 2008; } \\
\text { Riley et al., 2001; Russelle et al., 1983, Shedeed et al., 2009; } \\
\text { Vetsch and Randall, 2004; Yoseftabar et al., 2014. }\end{array}$ & & $\begin{array}{l}\text { ontrol or } \\
\text { hedulin }\end{array}$ & in the \\
\hline Texture & $\begin{array}{l}\text { Coarse soils favor } \\
\text { lixiviation. }\end{array}$ & Asadi et al., 2002; Vlek et al., 1980; Zotarelli et al., 2007. & & $(0)$ & \\
\hline $\begin{array}{l}\text { Types of } \mathrm{N} \\
\text { molecules }\end{array}$ & $\begin{array}{l}\text { Nitrates more prone to } \\
\text { lixiviation than } \\
\text { ammonia or urea, } \\
\text { especially for high } \\
\text { water contents. }\end{array}$ & $\begin{array}{l}\text { Asadi et al., 2002; Badr and El-Yazied, 2007; Hanson et al., } \\
\text { 2006; Haynes, 1985; Santos et al., } 1997 .\end{array}$ &.$(+$ & + +) & $(-)$ \\
\hline Water content & $\begin{array}{c}\text { Near-saturation and 1D } \\
\text { geometries favor } \\
\text { lixiviation, 3D } \\
\text { infiltration patterns } \\
\text { reduce it. }\end{array}$ & $\begin{array}{l}\text { Burguete et al., 2009; Darwish et al., 2003; Mubarak et al., } \\
\text { 2009; Murrell and Snyder, } 2006 .\end{array}$ & $(+$ & 十) & $(-)$ \\
\hline
\end{tabular}


Author-produced version of the article published in Agricultural Water Management, 2016, №178, p. 225-238.

The original publication is available at http://www.sciencedirect.com/science/article/pii/S0378377416303833

Doi: 10.1016/j.agwat.2016.09.027

Two factors must be taken in consideration to decide the location of the fertilizer. The first factor is the root distribution during the crop growth period (Zeng et al., 2001). Where irrigation is needed, root growth and distribution pattern are generally restricted to the wetted soil volume under the irrigation system (Gardenäs et al., 2005). Thus, the nutrients applied outside this area might not be used by crop roots, being more susceptible to leach below the rooting zone (Haynes, 1986; Siyal et al., 2012; Wiesler and Horst, 1994). The second, complementary factor is to account for the geometrical characteristics of water delivery in the irrigation system, with a trend to increased lixiviation risks for 1D saturated geometries (sprinkler, flood irrigation) in comparison with fertigation in the $2 \mathrm{D}$ or $3 \mathrm{D}$ flow patterns associated with DI or SDI (Burguete et al., 2009; Darwish et al., 2003; Mailhol et al., 2001; Mubarak et al., 2009).

Recommendations on the timing and duration of fertigation within irrigation events seem to vary between authors, irrigation techniques and site specificities. For example, Gärdenäs et al. (2005), for long-duration micro-irrigations, demonstrated that the largest leaching losses occurred when starting the 2-h fertigation $1 \mathrm{~h}$ after the beginning of the irrigation cycle. On the contrary, the smallest leaching losses were obtained when starting the 2-h fertigation $3 \mathrm{~h}$ before the irrigation cutoff. As most studies, Hanson et al. (2006) tend to agree with that recommendation while Cote et al. (2003) rather recommend fertigation early in the irrigation cycle.

For most irrigated crops, nitrogen demand and uptake are low at the beginning of the growth stage but drastically increase around the middle of the vegetative growth stage, until at least the first reproductive stage (Gallais and Hirel, 2004; Jokela and Randall, 1989; Russelle et al., 1983). Nitrogen applications should therefore take place during the period of strong crop demand, to ensure maximal efficiency and also to prevent losses by lixiviation (Hassan et al., 2010; Randall and Sawyer, 2008; Riley et al., 2001). A proper timing of fertilization must account for the time lag between nitrogen application and the onset of plant demand: pre-emergence fertilization is associated with increased contamination risks (Dinnes et al., 2002; Prunty and Greenland, 1997; Vetsch and Randall, 2004). However, nitrogen applications just before or at planting may be favorable to avoid nitrogen stresses during early plant growth, when compared to applications a few days later, near the emergence date (Sangoi et al., 2007). Dose splitting (the application of nitrogen at multiple, appropriate times 
Author-produced version of the article published in Agricultural Water Management, 2016, №178, p. 225-238.

The original publication is available at http://www.sciencedirect.com/science/article/pii/S0378377416303833

Doi: 10.1016/j.agwat.2016.09.027

during the cropping season) has been widely advocated to reduce the lixiviation and denitrification losses as well, saving $25-50 \%$ of the nitrogen supply costs (Cote et al., 2003; Gärdenäs et al., 2005; Hanson et al., 2006; Mmolawa and Or, 2000; Shedeed et al., 2009). Dose splitting aims at better meeting plant needs and root demands at the different stages of crop growth (Li et al., 2005, Mailhol et al., 2001, Yoseftabar et al., 2014). For spring crops, nitrogen applications in autumn, before the agricultural season, is prone to avoid nitrification but increases the risk of nitrogen losses by leaching or denitrification. On the contrary, delaying the application to spring is prone to decrease lixiviation and to increase nitrogen use efficiency by 10-15\% (Dinnes et al., 2002; Randall and Sawyer, 2008). Moreover, if one decides to supply nitrogen in autumn for spring crops, the $\mathrm{NH}_{3}$ form (anhydrous ammonia) should be used and buried at $15 \mathrm{~cm}$ or more to facilitate the conversion to ammonium $\left(\mathrm{NH}_{4}{ }^{+}\right)$ and limit the losses by volatilization.

Soil properties are generally known before the choice of a type of molecule is made, so that soil properties may dictate the type of molecules used in a number of cases. Lixiviation typically occurs in the coarsest soils because of their high water conductivity and low ability to retain the $\mathrm{NO}_{3}{ }^{-}$anions (Asadi et al., 2002; Zotarelli et al., 2007). Conversely, clayey soils have a low permeability with lesser leaching risks (Vlek et al., 1980). Although plant roots may absorb nitrates $\mathrm{NO}_{3}{ }^{-}$, ammonium $\mathrm{NH}_{4}{ }^{+}$and urea $\mathrm{CO}\left(\mathrm{NH}_{2}\right)_{2}$, the behavior of these nitrogen forms is not equal in the wetted soil, and differences in nitrogen losses may arise from the types of molecules used for fertilization. Nitrates losses have been related to their high mobility and solubility in water (Badr and El-Yazied, 2007) and to the low ability of most soils to retain it, due to the negative charge of soil particles (Asadi et al., 2002). Nitrates are transported mainly by convection, thus expected to leach below the rooting zone if rainfall or irrigation (FI and SI) exceeds the field capacity and potential evapotranspiration of the soil plant system (Santos et al., 1997). Unlike nitrates, ammonium is retained by the negatively charged soil particles, especially when it is injected below the soil surface (SDI), which makes it virtually immobile thus minimizes the lixiviation risk (Hanson et al., 2006). Earlier studies (e.g. Haynes, 1985) found that ammonium applied by DI concentrated in the $10 \mathrm{~cm}$ below the dripper, with little lateral movement. By contrast, urea and nitrates had both moved vertically to soil depths of about $70 \mathrm{~cm}$ below the emitter and laterally up to $30 \mathrm{~cm}$ from the point of application (Badr and El-Yazied, 2007). 
Author-produced version of the article published in Agricultural Water Management, 2016, №178, p. 225-238.

The original publication is available at http://www.sciencedirect.com/science/article/pii/S0378377416303833

Doi: 10.1016/j.agwat.2016.09.027

Nitrate, ammonium and urea are the main forms of nitrogen fertilizers taken up by plant roots. These molecules have a different behavior in soil and a different effect on the cations vs. anions balance, thus on soil pH. For example, for nitrate-based fertilizers, plants will absorb the nitrates (anions) thus leave the cations in the rhizopsphere, before exuding $\mathrm{OH}$ - ions to reestablish the local balance between $\mathrm{H}+$ and $\mathrm{OH}$ - ions, which increases soil $\mathrm{pH}$. Conversely, plant roots exude $\mathrm{H}+$ ions if ammonium-based fertilizers or urea are used and absorbed: soil acidification is then induced, which decreases soil $\mathrm{pH}$ and creates unfavorable conditions for mineralization: more fertilizer is thus expectedly available for lixiviation (Hinsinger et al., 2003).

\section{Implications to agricultural water management}

An illustration of typical agricultural cases is proposed in Fig. 2, assembled from

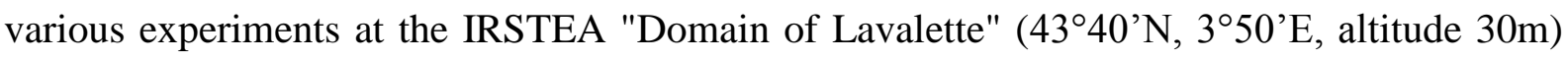
in Montpellier, France) showing data collected in spring and summer 2014 on several plots equipped with specific, independent irrigation systems. Two Campbell CR10X dataloggers were used to record soil temperatures from Pt100 probes (limited to the 5, 15 and $25 \mathrm{~cm}$ depths on all plots, not shown) and water contents (from TDR probes) at a 20-minute time step at several depths. The signals were collected for the 0-10, 10-20, 20-30 and 30-40 cm depths on the non-irrigated plot as well as on the adjacent plot, irrigated by sprinklers. The signals were collected at 0-10, 10-20, 20-30, 30-40, 40-50 and 50-60 cm depths for the other plots. The period of data collection was June 2 to August 11 and Fig. 2 shows results obtained between June 13 and June 22. The soil is predominantly loamy and deep, containing on average $18 \%$ of clay, $47 \%$ silt and $35 \%$ sand over the maximal rooting depth of maize. The local hydrodynamic properties are known from experimental campaigns performed on a regular basis: the last campaign took place after the installation of a new subsurface drip irrigation network (buried at $35 \mathrm{~cm}$ depth) in the winter 2013/14.

Figure 2a to $\mathrm{d}$ shows saturation indices averaged over the first $30 \mathrm{~cm}$ of soil, in absence of irrigation ( $\varnothing \mathrm{I}$, Fig. 2a), under sprinkler irrigation (SI, Fig. 2b), drip irrigation (DI, Fig. 2c) and subsurface drip irrigation (SDI, Fig. 2d). Flood irrigation (FI, Fig.2b) was not performed but is presented here for classification purpose, showing more similarities with SI than with any other technique when considering the water content dynamics (even if complete soil submersion results in increased duration of soil saturation or near-saturation in the topsoil 
Author-produced version of the article published in Agricultural Water Management, 2016, №178, p. 225-238.

The original publication is available at http://www.sciencedirect.com/science/article/pii/S0378377416303833

Doi: 10.1016/j.agwat.2016.09.027

layers). Figure $2 \mathrm{e}$ to $\mathrm{h}$ describes the effects of the same irrigation techniques (or these of the absence of irrigation) on the saturation indices averages over soil depths between 30 and 40 $\mathrm{cm}$. Although the measurement technique used for data collection (TDR probes) does not offer high-resolution absolute values, their precision is enough to identify the differences between typical soil saturation profiles, associated with the various irrigation techniques.

Leaning on the cited literature elements, Fig. 2 indicates where nitrogen fluxes and transformations are most likely to occur, that is when considering soil water content as their first-order determinant and assuming all other things to be equal (i.e. no noticeable differences in the second-order determinants between the monitored plots). In Fig.2 and in the following, the notations $[\mathrm{N}],[\mathrm{D}],[\mathrm{R}],[\mathrm{V}],[\mathrm{M}],[\mathrm{F}]$ and $[\mathrm{L}]$ indicate "favorable" (or maybe risky) conditions for nitrification, denitrification, runoff, volatilization, mineralization, symbiotic fixation and lixiviation, respectively. The purpose and added value of Fig.2 is therefore to provide a comprehensive picture of the expected influence of the irrigation technique on the elements of the nitrogen cycle, thus, in turn, on the nitrogen budget (at least in qualitative terms and with respect to the first-order effects directly linked to the soil water content profiles).

The implications for agricultural water and nitrogen management are several, though depending on the degrees of freedom at the practitioner's disposal in choosing the irrigation technique and/or the crop and/or the irrigation and fertilization strategy. In the typical case of a known soil type (characterized by its $\mathrm{C} / \mathrm{N}$ ratio, $\mathrm{pH}$, salinity, temperature, texture, i.e. all secondary-order controls for nitrogen transformations listed in Tables 1 to 4) with no choice on the irrigation technique (e.g. sprinkler irrigation: SI), Fig.2b and $\mathrm{f}$ indicates which nitrogen transformation and fluxes may likely occur, together with the timing in which they take place. In this example, $[\mathrm{D}],[\mathrm{R}],[\mathrm{V}]$ and $[\mathrm{M}]$ depend on the irrigation amount (especially the peak in water content) while $[\mathrm{N}]$ rather depends on the time interval between successive irrigations and $[\mathrm{L}]$ depends on the irrigation amount first, but also on the series of factors listed in Table 5 (fertilizer location, scheduling of applications, soil texture, type of molecules). More generally, Fig.2 may be used as a reading grid, for guidance or to decipher the effects of irrigation and fertilization strategies, in terms of expected trends, possibly seeking confirmation in local soil water content measurements. However, these main trends may also be altered by particular values of the above mentioned second-order factors, hence 
recommending the use of Fig.2 as an entry point and that of Tables 1 to 5 for contextdependent verifications.

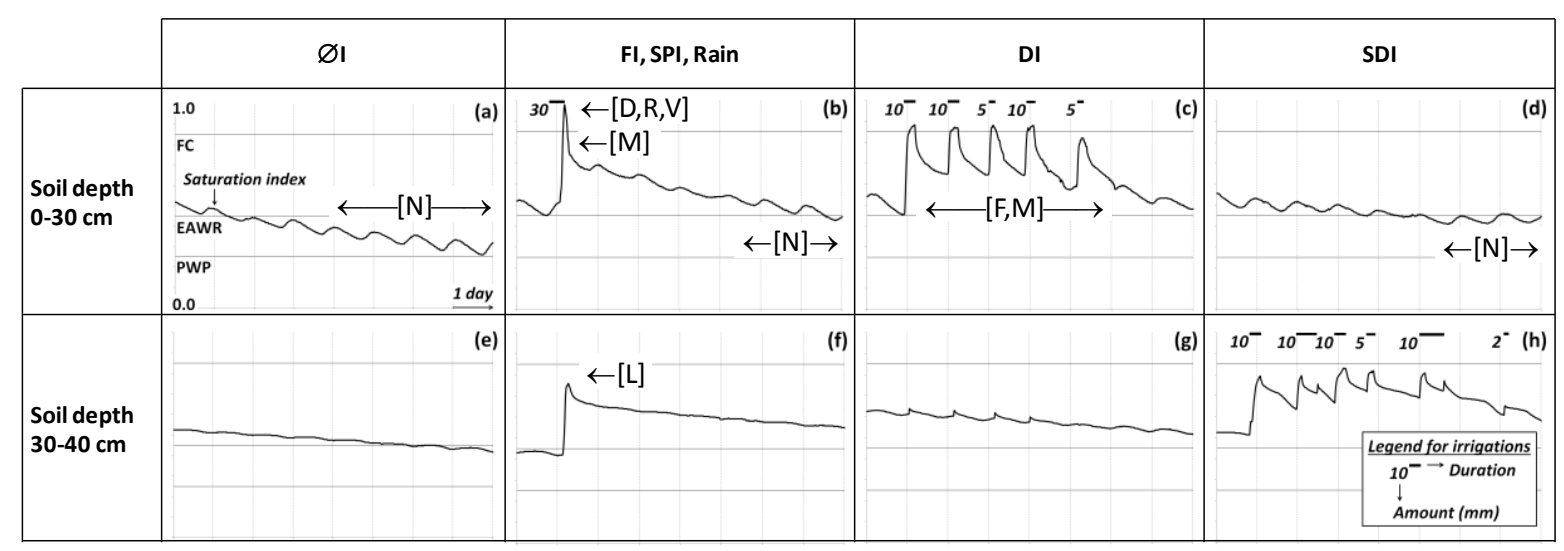

Figure 2 - Summary of the expected influence of the irrigation techniques on the nitrogen cycle, as mainly depending on soil water content, represented here by the evolution of the saturation index ( $y$ axis) with time ( $x$ axis), averaged over different soil depths $(0-30$ and $30-40 \mathrm{~cm})$. Here, $\varnothing \mathrm{I}$ indicates no irrigation, FI flood irrigation, SI sprinkler irrigation, DI drip irrigation, SDI subsurface drip irrigation. FC is field capacity, EAWR the limit of easily available water reserve and PWP the permanent wilting point. Depending on other contextual elements (see Tables 1 to 5), [N], $[D],[R],[V],[M]$ and $[\mathrm{F}]$ indicate favorable conditions for nitrification, denitrification, runoff, volatilization, mineralization and fixation, while $[\mathrm{L}]$ indicates lixiviation risks. The plotted data have been collected on several cultivated plots (maize) on the experimental site of Lavalette (IRSTEA Montpellier), for different 10-day periods in spring and summer 2014. Sketches (a) to (h) were chosen to account for "typical situations" and not for detailed comparisons, as briefly discussed in the text, as the tested irrigation strategies were not designed for the present paper.

A complementary representation is proposed in Fig. 3, which exposes the same arguments in a different way. Figure 3 adapts Fig. 1 with the main outcomes of the present review, indicating the preferential associations between irrigation techniques $\varnothing$ I, SI, DI, $\mathrm{SDI})$ and nitrogen fluxes or transformations ([N], $[\mathrm{D}],[\mathrm{V}],[\mathrm{M}],[\mathrm{F}],[\mathrm{L}])$, i.e. the "active" connections in the chart, once the irrigation technique is known. This allows identifying the merits and drawbacks of (hypothesized) classical strategies associated with the irrigation techniques, for example large irrigation amounts with time intervals of several days for sprinkler irrigation. 


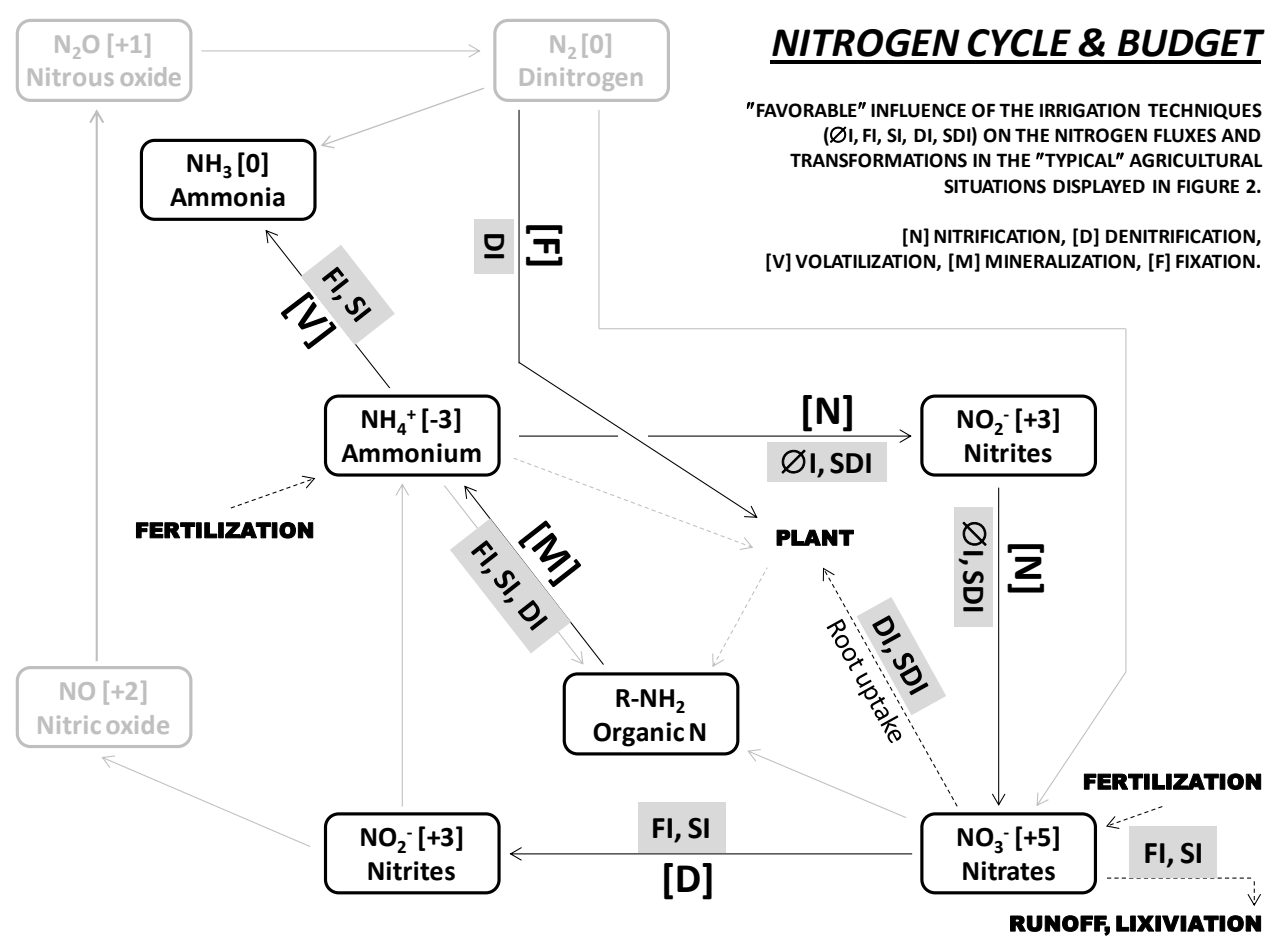

Figure 3 - Schematic overview of the nitrogen cycle and budget, showing the expected favorable influence of the irrigation techniques $(\varnothing \mathrm{I}$ : no irrigation, FI: flood irrigation, SI: sprinkler irrigation, DI: drip irrigation, SDI: subsurface drip irrigation) on the main nitrogen fluxes and transformations, in "typical situations" for agricultural contexts, as shown in Fig.2. [N] accounts for favorable conditions for nitrification, [D] for denitrification, [V] for volatilization, $[\mathrm{M}]$ for mineralization and $[\mathrm{F}]$ for (symbiotic) fixation.

\section{Conclusion}

This academic, mostly qualitative review tries to bridge the gap between detailed biochemical studies on nitrogen transformations and fluxes in agricultural soils on the one hand and studies on irrigation techniques and strategies on the other hand. To the authors knowledge, no such overview and comprehensive picture was available to assess the influence of the irrigation techniques on the nitrogen cycle and budget, at least at the chosen intermediate level of complexity that addresses first-order and second-order effects while deliberately discarding the finer details. A wide consensus exists in the literature that the temporal evolution of soil water content profile directly dictates most nitrogen transformations (symbiotic fixation, mineralization, immobilization, nitrification) and fluxes (denitrification, runoff, volatilization and lixiviation) while multiple secondary factors may intervene (soil $\mathrm{C} / \mathrm{N}$ ratio, $\mathrm{pH}$, salinity, temperature and texture for nitrogen transformations, fertilizer location and scheduling of applications, soil texture and type of molecules for nitrogen fluxes). As irrigation techniques (furrow irrigation, sprinkler irrigation, surface and 
subsurface drip irrigation) and strategies may both be characterized by specific patterns of soil water content in space and time, this endows practitioners with several efficient degrees of freedom in deciding agricultural water and nitrogen management practices. Assuming the best decisions are taken when comparisons are possible, this review summarizes typical agricultural situations in simplified, graphical overviews that indicate which irrigation techniques tend to favor which nitrogen transformations and fluxes (at the need of indirect confirmations in the form of local soil water content measurements and the examination of all known secondary factors).

The overview gained on the expected relevant or risky associations between irrigation and fertilization strategies (especially with the benefit of previous in situ experiences) may also be used to decipher more relevant site-specific combined strategies. Fertilization management options especially impact volatilization, runoff and lixiviation fluxes, the latter more complex in their processes but far more plausible for occasionally large irrigation amounts, or the coincidental occurrence of strong rain events soon after fertilization. However, a series of mitigation effects is known from literature and consists in the choice of the right type of molecules (nitrates instead of urea is risky in coarse soils), their application of appropriate doses (meeting plant demands) at relevant locations (where roots will find the fertilizer-depending on the irrigation technique) within a clever scheduling (within-event and/or within-season dose splitting). Finally, furrow irrigation and sprinkler irrigation appear to be the irrigation techniques with the strongest, more numerous and less controlled effects on the nitrogen transformations and fluxes (unless dedicated attention is paid). By contrast, subsurface drip irrigation seems to be the irrigation technique with potentially the least effect on soil's nitrogen cycle, possibly meeting root demands at best, provided roots have grown to a sufficient depth.

\section{Acknowledgements}

[After acceptance of the manuscript] 
Author-produced version of the article published in Agricultural Water Management, 2016, №178, p. 225-238.

The original publication is available at http://www.sciencedirect.com/science/article/pii/S0378377416303833

Doi: 10.1016/j.agwat.2016.09.027

\section{References}

Addiscott, T. M., 2005. Nitrate, agriculture and the environment. CAB International, Wallingford, UK, 279 pp.

Agehara, S., Warncke, D.D., 2005. Soil Moisture and Temperature Effects on Nitrogen Release from Organic Nitrogen Sources. Soil Science Society of America Journal 69(6), 1844-1855.

Albrecht, S.L., Bennett, J.M., Boote, K.J., 1984. Relationship of nitrogenase activity to plant water stress in field-grown soybeans. Field Crops Research 8, 61-71.

Alexandratos, N., Bruinsma, J., 2012. World agriculture towards 2030/2050, the 2012 revision. ESA Working Paper No. 12-03, June 2012. Rome: Food and Agriculture Organization of the United Nations (FAO).

Al-Kanani, T., MacKenzie, A. F., Barthakur, N. N., 1991. Soil water and ammonia volatilization relationships with surface-applied nitrogen fertilizer solutions. Soil Science Society of America Journal 55(6), 1761-1766.

Aoyama, M., 1991. Properties of Fine and Water-Soluble Fractions of Several Composts: II. Organic Forms of Nitrogen, Neutral Sugars, and Muramic Acid in Fractions. Soil Science and Plant Nutrition 37, 629-637

Arp, D.J., Sayavedra-Soto, L.A., Hommes, N.G., 2002. Molecular biology and biochemistry of ammonia oxidation by Nitrosomonas europaea. Arch Microbiol 178, 250-255.

Aulakh, M.S., Doran, J.W., Walters, D.T., Power, J.F., 1991. Legume residue and soil water effects on denitrification in soils of different textures. Soil Biology and Biochemistry 23, $1161-1167$.

Asadi, M. E., Clemente, R. S., Gupta, A. D., Loof, R., Hansen, G. K., 2002. Impacts of fertigation via sprinkler irrigation on nitrate leaching and corn yield in an acid-sulphate soil in Thailand. Agricultural Water Management 52(3), 197-213.

Azam, F., Simmons, F.W., Mulvaney, R.L., 1993. Immobilization of ammonium and nitrate and their interaction with native $\mathrm{N}$ in three Illinois Mollisols. Biol Fertil Soils 15, 50-54.

Badr, M. A., El-Yazied, A. A., 2007. Effect of fertigation frequency from subsurface drip irrigation on tomato yield grown on sandy soil. Aust. J. Basic Appl. Sci 1(3), 279-285.

Bailey, L.D., 1976. Effects of temperature and root on denitrification in a soil. Canadian Journal of Soil Science 56, 79-87.

Bassirirad, H., 2000. Kinetics of nutrient uptake by roots: responses to global change, New Phytologist 147(1), 155-169. 
Author-produced version of the article published in Agricultural Water Management, 2016, №178, p. 225-238.

The original publication is available at http://www.sciencedirect.com/science/article/pii/S0378377416303833

Doi: 10.1016/j.agwat.2016.09.027

Bell, A. A., Liu, L., Reidy, B., Davis, R. M., Subbarao, K. V., 1998. Mechanisms of subsurface drip irrigation-mediated suppression of lettuce drop caused by sclerotinia minor. Phytopathology 88(3), 252-259.

Bengtsson, G., Bengtson, P., Månsson, K.F., 2003. Gross nitrogen mineralization-, immobilization-, and nitrification rates as a function of soil $\mathrm{C} / \mathrm{N}$ ratio and microbial activity. Soil Biology and Biochemistry 35, 143-154.

Berstein, L., Ogata, G., 1966. Effects of Salinity on Nodulation, Nitrogen Fixation, and Growth of Soybeans and Alfalfa1, Agronomy Journal 58, 201-203.

Birch, H.F., 1958. The effect of soil drying on humus decomposition and nitrogen availability. Plant Soil 10, 9-31.

Boer, W.D., Gunnewiek, P.J.A.K., Veenhuis, M., Bock, E., Laanbroek, H.J., 1991). Nitrification at low $\mathrm{pH}$ by aggregated chemolithotrophic bacteria. Appl. Environ. Microbiol. $57,3600-3604$.

Bora, P. K., Ray, L. I. P., 2015. Soil acidification due to point application of fertilizers through drip irrigation. Journal of AgriSearch 2(2), 100-104.

Bordeleau, L.M., Prévost, D., 1994. Nodulation and nitrogen fixation in extreme environments, in: Graham, P.H., Sadowsky, M.J., Vance, C.P., Eds.), Symbiotic nitrogen fixation, Developments in Plant and Soil Sciences. Springer Netherlands, 115-125.

Borken, W., Matzner, E., 2009. Reappraisal of drying and wetting effects on C and N mineralization and fluxes in soils. Global Change Biology 15, 808-824.

Bremner, J.M., Shaw, K., 1958. Denitrification in soil. II. Factors affecting denitrification. The Journal of Agricultural Science 51, 40-52.

Brierley, E.D.R., Wood, M., Shaw, P.J.A., 2001. Influence of tree species and ground vegetation on nitrification in an acid forest soil. Plant and Soil 229, 97-104.

Brockwell, J., Whalley, R., 1970. Studies on seed pelleting as an aid to legume seed inoculation. 2. Survival of Rhizobium meliloti applied to medic seed sown into dry soil. Aust. J. Exp. Agric. 10, 455-459.

Bruning, B., Rozema, J., 2013. Symbiotic nitrogen fixation in legumes: Perspectives for saline agriculture. Environmental and Experimental Botany, Sustainable cultivation and exploitation of halophyte crops in a salinizing world 92, 134-143.

Burford, J.R., Bremner, J.M., 1975. Relationships between the denitrification capacities of soils and total, water-soluble and readily decomposable soil organic matter. Soil Biology and Biochemistry 7, 389-394.

Burger, M., Jackson, L.E., 2003. Microbial immobilization of ammonium and nitrate in 
Author-produced version of the article published in Agricultural Water Management, 2016, №178, p. 225-238.

The original publication is available at http://www.sciencedirect.com/science/article/pii/S0378377416303833

Doi: 10.1016/j.agwat.2016.09.027

relation to ammonification and nitrification rates in organic and conventional cropping systems. Soil Biology and Biochemistry 35, 29-36.

Burger, M., Jackson, L.E., Lundquist, E.J., Louie, D.T., Miller, R.L., Rolston, D.E., Scow, K.M., 2005. Microbial responses and nitrous oxide emissions during wetting and drying of organically and conventionally managed soil under tomatoes. Biol Fertil Soils 42, 109-118.

Burguete, J., Zapata, N., García-Navarro, P., Maïkaka, M., Playán, E., Murillo, J., 2009. Fertigation in furrows and level furrow systems. II: Field experiments, model calibration, and practical applications. Journal of irrigation and drainage engineering 135, 413-420.

Cabrera, M.L., 1993. Modeling the Flush of Nitrogen Mineralization Caused by Drying and Rewetting Soils. Soil Science Society of America Journal 57(1), 63-66.

Cameron, K.C., Di, H.J., Moir, J.L., 2013. Nitrogen losses from the soil/plant system: a review. Annals of Applied Biology 162, 145-173.

Cheng, Y., Wang, J., Mary, B., Zhang, J., Cai, Z., Chang, S.X., 2013. Soil pH has contrasting effects on gross and net nitrogen mineralizations in adjacent forest and grassland soils in central Alberta, Canada. Soil Biology and Biochemistry 57, 848-857.

Colaizzi, P. D., Evett, S. R., Howell, T. A., 2004. Comparison of SDI, LEPA, and spray irrigation performance for cotton in the North Texas High Plains. In CD-ROM. Irrigation Association Annual Meeting 14-16 Nov, Tampa, FL.

Cote, C. M., Bristow, K. L., Charlesworth, P. B., Cook, F. J., Thorburn, P. J., 2003. Analysis of soil wetting and solute transport in subsurface trickle irrigation. Irrigation Science 22(3-4), 143-156.

Dalias, P., Anderson, J.M., Bottner, P., Coûteaux, M.-M., 2002. Temperature responses of net nitrogen mineralization and nitrification in conifer forest soils incubated under standard laboratory conditions. Soil Biology and Biochemistry 34, 691-701.

Davidson, E.A., 1992. Sources of Nitric Oxide and Nitrous Oxide following Wetting of Dry Soil. Soil Science Society of America Journal 56(1), 95-102.

Darwish, T., Atallah, T., Hajhasan, S., Chranek, A., 2003. Management of nitrogen by fertigation of potato in Lebanon. Nutrient Cycling in Agroecosystems 67(1), 1-11.

De Boer, W., Kowalchuk, G.A., 2001. Nitrification in acid soils: micro-organisms and mechanisms. Soil Biology and Biochemistry 33, 853-866.

De Klein, C.A.M., Van Logtestijn, R.S.P., 1996. Denitrification in grassland soils in The Netherlands in relation to irrigation, $\mathrm{N}$-application rate, soil water content and soil temperature. Soil Biology and Biochemistry 28, 231-237.

Dinnes, D. L., Karlen, D. L., Jaynes, D. B., Kaspar, T. C., Hatfield, J. L., Colvin, T. S., 
Author-produced version of the article published in Agricultural Water Management, 2016, №178, p. 225-238.

The original publication is available at http://www.sciencedirect.com/science/article/pii/S0378377416303833

Doi: 10.1016/j.agwat.2016.09.027

Cambardella, C. A., 2002. Nitrogen management strategies to reduce nitrate leaching in tiledrained Midwestern soils. Agronomy journal 94(1), 153-171.

Dommergues, Y.R., Belser, L.W., Schmidt, E.L., 1978. Limiting Factors for Microbial Growth and Activity in Soil, in: Alexander, M., Ed.), Advances in Microbial Ecology. Springer US, 49-104.

Ebrahimian, H., Liaghat, A., Parsinejad, M., Playán, E., Abbasi, F., Navabian, M., 2013. Simulation of 1D surface and 2D subsurface water flow and nitrate transport in alternate and conventional furrow fertigation. Irrigation Science 31, 301-316.

Evett, S. R., Colaizzi, P. D., Howell, T. A., 2005. Drip and evaporation. In Proc. Central Plains Irrigation Conf., Sterling, CO., USA., Feb 2005, pp.16-17.

Feng, Q., Cao, J., Chen, L.-N., Guo, C.-Y., Tan, J., Xu, H., 2011. Simultaneous nitrification and denitrification at variable $\mathrm{C} / \mathrm{N}$ ratio in aerobic granular sequencing batch reactors. Journal of Food, Agriculture \& Environment 9, 1131-1136.

Ferguson, S. J., 1994. Denitrification and its control. Antonie van Leeuwenhoek, 66(1-3), 89110.

Fierer, N., Schimel, J.P., 2002. Effects of drying-rewetting frequency on soil carbon and nitrogen transformations. Soil Biology and Biochemistry 34, 777-787.

Fierer, N., Schimel, J.P., Holden, P.A., 2003. Influence of Drying-Rewetting Frequency on Soil Bacterial Community Structure. Microbial Ecology 45, 63-71.

Flury, M., 1993. Experimental evidence of transport of pesticides through field soils - a review, Journal of Environmental Quality 25, 25-45.Fowler, D., Coyle, M., Skiba, U., Sutton, M. A., Cape, J. N., Reis, S., Sheppard, L. J., Jenkins, A., Grizzetti, B., Galloway, J. N., Vitousek, P., Leach, A., Bouwman, A. F., Butterbach-Bahl, K., Dentener, F., Stevenson, D., Amann, M., Voss, M., 2013. The global nitrogen cycle in the twenty-first century, Philos. Trans. R. Soc. London, Ser. B, 368, 20130164

Fox, R.H., Myers, R.J.K., Vallis, I., 1990. The nitrogen mineralization rate of legume residues in soil as influenced by their polyphenol, lignin, and nitrogen contents. Plant Soil 129, 251259.

Franzluebbers, A.J., 1999. Microbial activity in response to water-filled pore space of variably eroded southern Piedmont soils, Applied Soil Ecology 11, 91-101.

Fu, M.H., Xu, X.C., Tabatabai, M.A., 1987. Effect of pH on nitrogen mineralization in cropresidue-treated soils, Biol Fert Soils 5, 115-119.

Gallais, A., Hirel, B., 2004. An approach to the genetics of nitrogen use efficiency in maize. Journal of Experimental Botany, 55(396), 295-306. 
Galloway, J. N., Schlesinger, W. H., Levy, H., Michaels, A., Schnoor, J. L., 1995. Nitrogen fixation: Anthropogenic enhancement-environmental response. Global Biogeochemical Cycles 9(2), 235-252.

Galloway, J. N., Dentener, F. J., Capone, D. G., Boyer, E. W., Howarth, R. W., Seitzinger, S. P., Asner, G. P., Cleveland, C. C., Green, P. A., Holland, E. A., Karl, D. M., Michaels, A. F., Porter, J. H., Townsend, A. R., Vörösmarty, C. J., 2004. Nitrogen Cycles: Past, Present, and Future, Biogeochemistry 70, 2), 153-206.

Galloway, J.N, Townsend, A. R., Erisman, J. W., Bekunda, M., Cai, Z., Freney, J. R., Martinelli, L. A., Seizinger, S. P., Sutton, M. A., 2008. Transformation of the Nitrogen cycle: recent trends, questions and potential solutions, Science 320, 889-892.

Gärdenäs, A. I., Hopmans, J. W., Hanson, B. R., Šimůnek, J., 2005. Two-dimensional modeling of nitrate leaching for various fertigation scenarios under micro-irrigation. Agricultural Water Management 74(3), 219-242.

Garg, N., Chandel, S., 2011. The effects of salinity on nitrogen fixation and trehalose metabolism in Mycorrhizal Cajanus cajan, L.) Millsp. Plants, Journal of Plant Growth and Regulation 30, 490-503.

Germon, J.-C., Couton, Y., 1999. La dénitrification dans les sols: régulation de son fonctionnement et applications à la dépollution. Courr. Environ. INRA 38, 67-74.

Gheysari, M., Mirlatifi, S.M., Homaee, M., Asadi, M.E., Hoogenboom, G., 2009. Nitrate leaching in a silage maize field under different irrigation and nitrogen fertilizer rates. Agricultural Water Management 96, 946-954.

Gilliam, J.W., Dasberg, S., Lund, L.J., Focht, D.D., 1978. Denitrification in four California soils: Effect of soil profile characteristics. Soil Science Society of America Journal 42, 61-66. Gruber, N., Galloway, J.N., 2008. An Earth-system perspective of the global nitrogen cycle, Nature 451, 293-296.

Gundersen, P., Emmett, B.A., Kjønaas, O.J., Koopmans, C.J., Tietema, A., 1998. Impact of nitrogen deposition on nitrogen cycling in forests: a synthesis of NITREX data. Forest Ecology and Management, The Whole Ecosystem Experiments of the NITREX and EXMAN Projects 101, 37-55.

Guntiñas, M.E., Leirós, M.C., Trasar-Cepeda, C., Gil-Sotres, F., 2012. Effects of moisture and temperature on net soil nitrogen mineralization: A laboratory study. European Journal of Soil Biology 48, 73-80.

Hafeez, F.Y., Aslam, Z., Malik, K.A., 1988. Effect of salinity and inoculation on growth, nitrogen fixation and nutrient uptake of Vigna radiata, L.) Wilczek. Plant Soil 106, 3-8. 
Author-produced version of the article published in Agricultural Water Management, 2016, №178, p. 225-238.

The original publication is available at http://www.sciencedirect.com/science/article/pii/S0378377416303833

Doi: 10.1016/j.agwat.2016.09.027

Han, J., Shi, J., Zeng, L., Xu, J., Wu, L., 2015. Effects of nitrogen fertilization on the acidity and salinity of greenhouse soils. Environmental Science and Pollution Research 22(4), 29762986.

Hanson, B. R., Šimůnek, J., Hopmans, J. W., 2006. Evaluation of urea-ammonium-nitrate fertigation with drip irrigation using numerical modeling. Agricultural Water Management, 86(1), 102-113.

Hassan, S. W., Oad, F. C., Tunio, S., Gandahi, A. W., Siddiqui, M. H., Oad, S. M., Jagirani, A. W., 2010. Effect of $\mathrm{N}$ application and $\mathrm{N}$ splitting strategy on maize $\mathrm{N}$ uptake, biomass production and physio-agronomic characteristics. Sarhad Journal of Agriculture 26(4), 551558.

Hassink, J., Bouwman, L.A., Zwart, K.B., Bloem, J., Brussaard, L., 1993. Relationships between soil texture, physical protection of organic matter, soil biota, and $\mathrm{c}$ and $\mathrm{n}$ mineralization in grassland soils, Geoderma 57, 105-128.

Haynes, R. J., 1985. Principles of fertilizer use for trickle irrigated crops. Fertilizer Research 6(3), 235-255.

Haynes, R. J., 1986. Uptake and assimilation of mineral nitrogen by plants, in Mineral Nitrogen in the Plant-Soil System, Ed. R. J. Haynes, Orlando, FL, Academic Press, 303378.

Haynes, R. J., Swift, R. S., 1987. Effect of trickle fertigation with three forms of nitrogen on soil $\mathrm{pH}$, levels of extractable nutrients below the emitter and plant growth. Plant and Soil 102(2), 211-221.

Hinsinger, P., Plassard, C., Tang, C., Jaillard, B., 2003. Origins of root-mediated pH changes in the rhizosphere and their responses to environmental constraints: a review. Plant and Soil 248(1-2), 43-59.

Jackson, L.E., Burger, M., Cavagnaro, T.R., 2008. Roots, Nitrogen Transformations, and Ecosystem Services. Annual Review of Plant Biology 59, 341-363.

Janssen, B.H., 1996. Nitrogen mineralization in relation to C:N ratio and decomposability of organic materials. Plant and Soil 181, 39-45.

Jokela, W. E., Randall, G. W., 1989. Corn yield and residual soil nitrate as affected by time and rate of nitrogen application. Agronomy Journal 81(5), 720-726.

Kennedy, T.L., Suddick, E.C., Six, J., 2013. Reduced nitrous oxide emissions and increased yields in California tomato cropping systems under drip irrigation and fertigation. Agriculture, Ecosystems \& Environment 170, 16-27.

Keys, E., McConnell, W. J., 2005. Global change and the intensification of agriculture in the 
Author-produced version of the article published in Agricultural Water Management, 2016, №178, p. 225-238.

The original publication is available at http://www.sciencedirect.com/science/article/pii/S0378377416303833

Doi: 10.1016/j.agwat.2016.09.027

tropics. Global Environmental Change 15(4), 320-337.

Khalil, A., 2008. Simulation of Nitrogen Distribution in Soil with Drip Irrigation System. Journal of Applied Sciences 8, 3157-3165.

Kieft, T., Soroker, E., Firestone, M., 1987. Microbial biomass response to a rapid increase in water potential when dry soil is wetted, Soil Biology and Biochemistry 19, 119-126.

Klotz, M. G., Stein, L. Y., 2011. Research on Nitrification and Related Processes, Part 2, Vol 496. Elsevier Academic Press, Amsterdam, The Netherlands.

Knowles, R., 1982. Denitrification. Microbiol. Rev. 46, 43-70.

Kozlowski, T.T., 1976. Water Deficits and Plant Growth, Volume IV: Soil Water Measurement, Plant Responses, and Breeding for Drought Resistance. Academic Press, New York, 383p.

Kroeze, C., Aerts, R., Breemen, N. van, Dam, D. van, Hofschreuder, P., Hoosbeek, M., Klein, J. de, Hoek, K. van der, Kros, H., Oene, H. van, Oenema, O., Tietema, A., Veeren, R. van der, Vries, W. de, 2003. Uncertainties in the fate of nitrogen I: An overview of sources of uncertainty illustrated with a Dutch case study. Nutrient Cycling in Agroecosystems 66, 4369.

Kumar, D., Shivay, Y. S., 2008. Definitional glossary of Agricultural Terms (Vol. 1). IK International, New Delhi, 314p.

Laher, M., Avnimelech, Y., 1980. Nitrification inhibition in drip irrigation systems. Plant and Soil 55(1), 35-42.

Lambin, E. F., Turner II, B. L., Geist, H. J., Agbola, S. B., Angelsen, A.,Bruce, J. W., Coomes, O. T., Dirzo, R., Fischer, G. and Folke, C., 2001. The causes of land-use and landcover change: moving beyond the myths, Global Environmental Change 11(4), pp.261-269.

Lamm, F. R., Ayers, J. E., Nakayama, F. S., 2007. Microirrigation for Crop Production. Design, Operation, and Management. Elsevier Publications, Amsterdam, 608p.

Li, J., Zhang, J., Rao, M., 2004. Wetting patterns and nitrogen distributions as affected by fertigation strategies from a surface point source. Agricultural Water Management 67(2), 89104.

Lindström, K., Sarsa, M.-L., Polkunen, J., Kansanen, P., 1985. Symbiotic nitrogen fixation of Rhizobium, Galega) in acid soils, and its survival in soil under acid and cold stress. Plant Soil 87, 293-302.

Lloyd, D., 1993. Aerobic denitrification in soils and sediments: From fallacies to facts. Trends in Ecology \& Evolution 8, 352-356.

Long, G.-Q., Sun, B., 2012. Nitrogen leaching under corn cultivation stabilized after four 
Author-produced version of the article published in Agricultural Water Management, 2016, N¹78, p. $225-238$.

The original publication is available at http://www.sciencedirect.com/science/article/pii/S0378377416303833

Doi: 10.1016/j.agwat.2016.09.027

years application of pig manure to red soil in subtropical China. Agriculture, Ecosystems \& Environment 146, 73-80.

Lü, G. H., Song, J. Q., Bai, W. B., Wu, Y. F., Yuan, L., Kang, Y. H., 2015. Effects of different irrigation methods on micro-environments and root distribution in winter wheat fields. Journal of Integrative Agriculture 14(8), 1658-1672.

Mailhol, J., Ruelle, P., Nemeth, I., 2001. Impact of fertilisation practices on nitrogen leaching under irrigation. Irrigation Science 20(3), 139-147.

Malhi, S. S., Nyborg, M., Harapiak, J. T., 1998. Effects of long-term N fertilizer-induced acidification and liming on micronutrients in soil and in bromegrass hay. Soil and Tillage Research 48(1), 91-101.

Malhi, S.S., McGill, W.B., 1982. Nitrification in three Alberta soils: Effect of temperature, moisture and substrate concentration. Soil Biology and Biochemistry 14, 393-399.

Mikha, M.M., Rice, C.W., Milliken, G.A., 2005. Carbon and nitrogen mineralization as affected by drying and wetting cycles. Soil Biology and Biochemistry 37, 339-347.

Miller, A.E., Schimel, J.P., Meixner, T., Sickman, J.O., Melack, J.M., 2005. Episodic rewetting enhances carbon and nitrogen release from chaparral soils. Soil Biology and Biochemistry 37, 2195-2204.

Mmolawa, K., Or, D., 2000. Root zone solute dynamics under drip irrigation: A review. Plant and Soil 222, 163-190.

Mubarak, I., Mailhol, J. C., Angulo-Jaramillo, R., Bouarfa, S., Ruelle, P., 2009. Effect of temporal variability in soil hydraulic properties on simulated water transfer under highfrequency drip irrigation. Agricultural Water Management 96(11), 1547-1559.

Murrell, S., Snyder, C., 2006. Fall applied nitrogen in the corn belt: Questions and answers for corn. Available at www. back-tobasics. net/FallAppliedN. pdf, verified 20 Mar. 2013.

Muthukumarasamy, R., Revathi, G., Lakshminarasimhan, C., 1999. Influence of N fertilisation on the isolation of Acetobacter diazotrophicus and Herbaspirillum spp. from Indian sugarcane varieties, Biol. Fertil. Soils 29, 157-164.

Myers, R.J.K., Weier, K.L., Campbell, C.A., 1982. Quantitative relationship between net nitrogen mineralization and moisture content of soils. Canadian Journal of Soil Science 62, $111-124$.

Neve, S.D., Hofman, G., 2002. Quantifying soil water effects on nitrogen mineralization from soil organic matter and from fresh crop residues. Biol Fertil Soils 35, 379-386.

Niste, M., Vidican, R., Pop, R., Rotar, I., 2013. Stress factors affecting symbiosis activity and nitrogen fixation by Rhizobium cultured in vitro. ProEnvironment/ProMediu 6(13):42-45. 
Author-produced version of the article published in Agricultural Water Management, 2016, №178, p. 225-238.

The original publication is available at http://www.sciencedirect.com/science/article/pii/S0378377416303833

Doi: 10.1016/j.agwat.2016.09.027

Osemwota, I.O., Edosomwan, N.L., Okwuagwu, M., 2004. Mineralization of soil organic nitrogen - A review. Agricultural Reviews 25, 152-156.

Ouyang, Y., Li, X., 2013. Recent research progress on soil microbial responses to dryingrewetting cycles. Acta Ecologica Sinica 33, 1-6.

Parchomchuk, P., Neilsen, G. H., Hogue, E. J., 1993. Effects of drip fertigation of NH4-N and $\mathrm{P}$ on soil $\mathrm{pH}$ and cation leaching. Canadian Journal of Soil Science 73(2), 157-164.

Parkin, T.B., Sexstone, A.J., Tiedje, J.M., 1985. Adaptation of Denitrifying Populations to Low Soil pH. Appl. Environ. Microbiol. 49, 1053-1056.

Persson, T., Rudebeck, A., Jussy, J.H., Colin-Belgrand, M., Priemé, A., Dambrine, E., Karlsson, P.S., Sjöberg, R.M., 2000. Soil Nitrogen Turnover - Mineralisation, Nitrification and Denitrification in European Forest Soils, in: Schulze, P.D.E.-D., Ed.), Carbon and Nitrogen Cycling in European Forest Ecosystems, Ecological Studies. Springer Berlin Heidelberg, 297-311.

Persson, T., Wiren, A., 1995. Nitrogen mineralization and potential nitrification at different depths in acid forest soils. Plant and Soil 168, 55-65.

Pulleman, M., Tietema, A., 1999. Microbial $\mathrm{C}$ and $\mathrm{N}$ transformations during drying and rewetting of coniferous forest floor material. Soil Biology and Biochemistry 31, 275-285.

Prunty, L., Greenland, R., 1997. Nitrate leaching using two potato-corn N-fertilizer plans on sandy soil. Agriculture, Ecosystems \& Environment, 65(1), 1-13.

Qian, P., Schoenau, J.J., 2002. Availability of nitrogen in solid manure amendments with different C:N ratios. Canadian Journal of Soil Science 82, 219-225.

Randall, G.W., Sawyer, J.E., 2008. Nitrogen application timing, forms and additives. In: Final Report: Gulf Hypoxia and Local Water Quality Concerns Workshop, Upper Mississippi River Sub-Basin Hypoxia Nutrient Committee, American Society of Agricultural and Biological Engineers, St. Joseph, MI, pp.73-85.

Rao, D.L.N., Giller, K.E., Yeo, A.R., Flowers, T.J., 2002. The Effects of Salinity and Sodicity upon Nodulation and Nitrogen Fixation in Chickpea(Cicer arietinum). Ann Bot 89, 563-570.

Recous, S., Mary, B., Faurie, G., 1990. Microbial immobilization of ammonium and nitrate in cultivated soils. Soil Biology and Biochemistry 22, 913-922.

Reichenberger, S., Bach, M., Skitschak, A., Frede, H. G., 2007. Mitigation strategies to reduce pesticide inputs into ground- and surface water and their effectiveness; A review, Science of The Total Environment 384 (1-3), 1-35.

Rice, W.A., Olsen, P.E., Collins, M.M., 1995. Symbiotic effectiveness of Rhizobium meliloti at low root temperature. Plant Soil 170, 351-358. 
Rietz, D. N., Haynes, R. J., 2003. Effects of irrigation-induced salinity and sodicity on soil microbial activity. Soil Biology and Biochemistry 35(6), 845-854.

Riley, W. J., Ortiz-Monasterio, I., Matson, P. A., 2001. Nitrogen leaching and soil nitrate, nitrite, and ammonium levels under irrigated wheat in Northern Mexico. Nutrient Cycling in Agroecosystems 61(3), 223-236.

Rivett, M.O., Buss, S.R., Morgan, P., Smith, J.W.N., Bemment, C.D., 2008. Nitrate attenuation in groundwater: A review of biogeochemical controlling processes. Water Research 42, 4215-4232.

Russelle, M. P., Hauck, R. D., Olson, R. A., 1983. Nitrogen accumulation rates of irrigated maize. Agronomy Journal 75(4), 593-598.

Robertson, G.P., Groffman, P.M., 2007. Nitrogen transformations. Soil microbiology, ecology, and biochemistry, 3rd edn. Academic/Elsevier, New York, 341-364.

Ross, D.S., Lawrence, G.B., Fredriksen, G., 2004. Mineralization and nitrification patterns at eight northeastern USA forested research sites. Forest Ecology and Management 188, 317335.

Sahrawat, K.L., 1982. Nitrification in some tropical soils. Plant Soil 65, 281-286.

Sahrawat, K.L., Keeney, D.R., 1986. Nitrous Oxide Emission from Soils, in: Stewart, B.A.(Ed.), Advances in Soil Science, Advances in Soil Science. Springer New York, 103148.

Sanchez-Diaz, M., Aparicio-Tejo, P., Gonzalez-Murua, C., Peña, J. I., 1982. The effect of $\mathrm{NaCl}$ salinity and water stress with polyethylene glycol on nitrogen fixation, stomatal response and transpiration of Medicago sativa, Trifolium repen and Trifolium brachycalycinum (subclover), Physiol. Plant. 54, 361-366.

Sánchez-Martín, L., Vallejo, A., Dick, J., M Skiba, U., 2008. The influence of soluble carbon and fertilizer nitrogen on nitric oxide and nitrous oxide emissions from two contrasting agricultural soils. Soil Biology and Biochemistry 40, 142-151.

Sangoi, L., Ernani, P. R., Silva, P. R. F. D., 2007. Maize response to nitrogen fertilization timing in two tillage systems in a soil with high organic matter content. Revista Brasileira de Ciência do Solo 31(3), 507-517.

Santos, D. V., Sousa, P. L., Smith, R. E., 1997. Model simulation of water and nitrate movement in a level-basin under fertigation treatments. Agricultural Water Management 32(3), 293-306.

Sellstedt, A., Ståhl, L., Mattsson, U., Jonsson, K., Högberg, P., 1993. Can the 15N Dilution Technique be used to Study N2 Fixation in Tropical Tree Symbioses as Affected by Water 
Author-produced version of the article published in Agricultural Water Management, 2016, №178, p. 225-238.

The original publication is available at http://www.sciencedirect.com/science/article/pii/S0378377416303833

Doi: 10.1016/j.agwat.2016.09.027

Deficit? J. Exp. Bot. 44, 1749-1755.

Schepers, J. S., Varvel, G. E., Watts, D. G., 1995. Nitrogen and water management strategies to reduce nitrate leaching under irrigated maize. Journal of Contaminant Hydrology 20(3), 227-239.

Shedeed, S. I., Zaghloul, S. M., Yassen, A. A., 2009. Effect of method and rate of fertilizer application under drip irrigation on yield and nutrient uptake by tomato. Ozean Journal of Applied Sciences 2(2), 139-147.

Sierra, J., 1997. Temperature and soil moisture dependence of $\mathrm{N}$ mineralization in intact soil cores. Soil Biology and Biochemistry 29, 1557-1563.

Silva, J. A., Uchida, R. S., 2000. Plant Nutrient Management in Hawaii's Soils: Approaches for Tropical and Subtropical Agriculture. University of Hawaii at Manoa, 158p.

Sinclair, T.R., Muchow, R.C., Ludlow, M.M., Leach, G.J., Lawn, R.J., Foale, M.A., 1987. Field and model analysis of the effect of water deficits on carbon and nitrogen accumulation by soybean, cowpea and black gram. Field Crops Research 17, 121-140.

Siyal, A. A., Bristow, K. L., Šimůnek, J., 2012. Minimizing nitrogen leaching from furrow irrigation through novel fertilizer placement and soil surface management strategies, Agricultural Water Management 115, 242-251.

Skopp, J., Jawson, M., Doran, J., 1990. Steady-State Aerobic Microbial Activity as a Function of Soil-Water Content. Soil Sci. Soc. Am. J. 54, 1619-1625.

Soussi, M., Ocaña, A., Lluch, C., 1998. Effects of salt stress on growth, photosynthesis and nitrogen fixation in chick-pea (Cicer arietinum L.). J. Exp. Bot. 49, 1329-1337.

Sparling, G. P., Littler, R., Schipper, L. A., Stevenson, B., Sherman, L., Russell, J. M., 2015. Changes in characteristics of soils irrigated with processing wastewater from three New Zealand dairy factories. Soil Research 53(4), 448-460.

Stanford, G., Dzienia, S., Vander Pol, R.A., 1975. Effect of temperature on denitrification rate in soils. Soil Science Society of America Journal 39, 867-870.

Ste-Marie, C., Paré, D., 1999. Soil, pH and N availability effects on net nitrification in the forest floors of a range of boreal forest stands. Soil Biology and Biochemistry 31, 1579-1589.

Stevenson, F. J., Cole, M. A., 1999. Cycles of Soil: Carbon, Nitrogen, Phosphorus, Sulfur, Micronutrients, 2nd Edition. Wiley, New York, USA. 427p.

Stevenson, F.J., 1986. Cycles of Soil: carbon, nitrogen, phosphorus, sulfur, micronutrients. Wiley. New York. 380p.

Suddick, E.C., Steenwerth, K., Garland, G.M., Smart, D.R., Six, J., 2011. Discerning Agricultural Management Effects on Nitrous Oxide Emissions from Conventional and 
Author-produced version of the article published in Agricultural Water Management, 2016, №178, p. 225-238.

The original publication is available at http://www.sciencedirect.com/science/article/pii/S0378377416303833

Doi: 10.1016/j.agwat.2016.09.027

Alternative Cropping Systems: A California Case Study, in: Guo, L., Gunasekara, A.S., McConnell, L.L. (Eds.), Understanding Greenhouse Gas Emissions from Agricultural Management. American Chemical Society, Washington, DC, 203-226.

Sutton, M.A., Howard, C., Erisman, J.W., Billen, G., Bleeker, A., Grennfelt, P., van Grinsven, H., Grizzetti, B., 2011. The European Nitrogen Assessment, Cambridge University Press, Cambridge, UK, 612p.

Tarre, S., Green, M., 2004. High-Rate Nitrification at Low pH in Suspended- and AttachedBiomass Reactors. Appl Environ Microbiol 70, 6481-6487.

Tilman, D., Balzer, C., Hill, J., Befort, B. L., 2011. Global food demand and the sustainable intensification of agriculture. Proceedings of the National Academy of Sciences 108(50), 20260-20264.

Thorburn, P.J., Dart, I.K., Biggs, I.M., Baillie, C.P., Smith, M.A., Keating, B.A., 2003a. The fate of nitrogen applied to sugarcane by trickle irrigation. Irrigation Science 22, 201-209.

Thorburn, P.J., Cook, F.J., Bristow, K.L., 2003b. Soil-dependent wetting from trickle emitters: implications for system design and management. Irrigation Science 22, 121-127.

Trasar-Cepeda, C., Gil-Sotres, F., Leirós, M.C., 2007. Thermodynamic parameters of enzymes in grassland soils from Galicia, NW Spain. Soil Biology and Biochemistry 39, 311319.

Treusch, A.H., Leininger, S., Kletzin, A., Schuster, S.C., Klenk, H.-P., Schleper, C., 2005. Novel genes for nitrite reductase and Amo-related proteins indicate a role of uncultivated mesophilic crenarchaeota in nitrogen cycling. Environmental Microbiology 7, 1985-1995.

Valé, M., 2006. Quantification et prédiction de la minéralisation nette en azote du sol in situ, sous divers pédoclimats et systèmes de culture français. Ph.D. thesis, INPT-ENSAT, 183 pp + annexes

Valé, M., Mary, B., Justes, E., 2007. Irrigation practices may affect denitrification more than nitrogen mineralization in warm climatic conditions, Biology and fertility of soils 43 (6), 641651.

Van Grinsven, H. J. M., Ten Berge, H. F. M., Dalgaard, T., Fraters, B., Durand, P., Hart, A., Hofman, G., Jacobsen, B. H., Lalor, S. T. J., Lesschen, J. P., Osterburg, B., Richards, K. G., Techen, A.-K., Vertès, F., Webb, J., Willems, W. J., 2012. Management, regulation and environmental impacts of nitrogen fertilization in Northwestern Europe under the Nitrates Directive: a benchmark study. Biogeosciences 9(12), 5143-5160.

van Groenigen, J.W., Huygens, D., Boeckx, P., Kuyper, Th. W., Lubbers, I. M., Rütting, T., Groffman, P. M., 2015), The soil N cycle: new insights and key challenges, Soil 1, 235-256. 
Author-produced version of the article published in Agricultural Water Management, 2016, №178, p. 225-238.

The original publication is available at http://www.sciencedirect.com/science/article/pii/S0378377416303833

Doi: 10.1016/j.agwat.2016.09.027

Verberne, E.L.J., Hassink, J., Willigen, P. de, Groot, J.J.R., Veen, J.A. van, 1990. Modelling organic matter dynamics in different soils. Netherlands Journal of Agricultural Science 38, $221-238$.

Verhagen, F.J.M., Laanbroek, H.J., Woldendrop, J.W., 1995. Competition for ammonium between plant roots and nitrifying and heterotrophic bacteria and the effects of protozoan grazing. Plant and Soil 170, 241-250.

Verstraete, W., Focht, D.D., 1977. Biochemical Ecology of Nitrification and Denitrification, in: Alexander, M., Ed.), Advances in Microbial Ecology, Advances in Microbial Ecology. Springer US, 135-214.

Vetsch, J. A., Randall, G. W., 2004. Corn production as affected by nitrogen application timing and tillage. Agronomy Journal 96(2), 502-509.

Viero, F., Bayer, C., Vieira, R. C. B., Carniel, E., 2015. Management of irrigation and nitrogen fertilizers to reduce ammonia volatilization. Revista Brasileira de Ciência do Solo 39(6), 1737-1743.

Vitousek, P.M., Andariese, S.W., 1986. Microbial transformations of labelled nitrogen in a clear-cut pine plantation. Oecologia 68, 601-605.

Vitousek, P.M., Aber, J.D., Howarth, H.W., Likens, G.E., Matson, P.A., Schindler, D.W., Schlesinger, W.H., Tilman, D., 1997. Human alteration of the global nitrogen cycle: sources and consequences, Ecological Applications 7 (3), 737-750.

Vlek, P. L. G., Byrnes, B. H., \& Craswell, E. T., 1980. Effect of urea placement on leaching losses of nitrogen from flooded rice soils. Plant and Soil, 54(3), 441-449.

Wang, D., Shannon, M.C., Grieve, C.M., Yates, S.R., 2000. Soil water and temperature regimes in drip and sprinkler irrigation, and implications to soybean emergence. Agricultural Water Management 43, 15-28.

Wang, W. J., Chalk, P. M., Chen, D., Smith, C. J., 2001. Nitrogen mineralisation, immobilisation and loss, and their role in determining differences in net nitrogen production during waterlogged and aerobic incubation of soils. Soil Biology and Biochemistry 33(10), 1305-1315.

Ward, B. B., 2012. The Global Nitrogen Cycle. In: A. H. Knoll, D. E. Canfield and K. O. Konhauser, Editors, Fundamentals of Geomicrobiology, Wiley-Blackwell, Chichester, UK, 36-48.

Wiesler, F., Horst, W. J., 1994. Root growth and nitrate utilization of maize cultivars under field conditions. Plant and Soil 163(2), 267-277.

Wijler, J., Delwiche, C.C., 1954. Investigations on the denitrifying process in soil. Plant Soil 


\section{$5,155-169$.}

Xiang, S.-R., Doyle, A., Holden, P.A., Schimel, J.P., 2008. Drying and rewetting effects on C and $\mathrm{N}$ mineralization and microbial activity in surface and subsurface California grassland soils. Soil Biology and Biochemistry 40, 2281-2289.

Yoseftabar, S., 2012. Effect of split application of nitrogen fertilizer on leaf color chart values in hybrid rice (GRH1), International Journal of Biology 5 (1), 79-84.

Zahran, H.H., 1999. Rhizobium-Legume Symbiosis and Nitrogen Fixation under Severe Conditions and in an Arid Climate. Microbiol. Mol. Biol. Rev. 63, 968-989.

Zaman, M., Di, H. J., Cameron, K. C., 1999. A field study of gross rates of N mineralization and nitrification and their relationships to microbial biomass and enzyme activities in soils treated with dairy effluent and ammonium fertilizer. Soil Use and Management 15, 188-194.

Zeng, X., 2001. Global vegetation root distribution for land modeling. Journal of Hydrometeorology, 2(5), 525-530.

Zotarelli, L., Scholberg, J.M., Dukes, M.D., Muñoz-Carpena, R., 2007. Monitoring of Nitrate Leaching in Sandy Soils. Journal of Environment Quality 36(4), 953-962. 